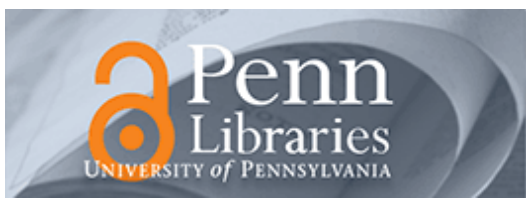

University of Pennsylvania ScholarlyCommons

Wharton Pension Research Council Working

Papers

Wharton Pension Research Council

$3-1-2008$

\title{
Optimizing the Equity-Bond-Annuity Portfolio in Retirement: The Impact of Uncertain Health Expenses
}

Gaobo Pang

Watson WyattWorldwide, Gaobo.Pang@watsonwyatt.com

Mark Warshawsky

Watson WyattWorldwide, Mark.Warshawsky@WatsonWyatt.com

Follow this and additional works at: https://repository.upenn.edu/prc_papers

Part of the Economics Commons

Pang, Gaobo and Warshawsky, Mark, "Optimizing the Equity-Bond-Annuity Portfolio in Retirement: The Impact of Uncertain Health Expenses" (2008). Wharton Pension Research Council Working Papers. 295.

https://repository.upenn.edu/prc_papers/295

This paper is posted at ScholarlyCommons. https://repository.upenn.edu/prc_papers/295

For more information, please contact repository@pobox.upenn.edu. 


\title{
Optimizing the Equity-Bond-Annuity Portfolio in Retirement: The Impact of Uncertain Health Expenses
}

\begin{abstract}
This paper derives optimal equity-bond-annuity asset portfolios for households in the retirement phase who, with or without a bequest motive, face stochastic capital market returns, have differential exposures to mortality risk and uncertain uninsured health expenses, and have differential Social Security and defined benefit pension coverage. The numerical results show that the presence of health spending risk drives households to shift their portfolios from risky equities to safer assets and works to enhance the demand for annuities due to their increasingwith-age superiority over bonds as a hedge against life-contingent health spending as well as longevity risks. The safe and higher-return annuities in turn provide a greater leverage for equity investment in the remaining asset portfolios. This health-spending-uncertainty-enhanced optimal annuitization result is compatible with the broader theory about liquidity constraints and precautionary savings.
\end{abstract}

\section{Disciplines}

Economics 


\title{
Optimizing the Equity-Bond-Annuity Portfolio in Retirement: The Impact of Uncertain Health Expenses
}

\author{
Gaobo Pang and Mark Warshawsky
}

March 2008

\author{
PRC WP2008-05 \\ Pension Research Council Working Paper \\ Pension Research Council \\ The Wharton School, University of Pennsylvania \\ 3620 Locust Walk, 3000 SH-DH \\ Philadelphia, PA 19104-6302 \\ Tel: 215.898.7620 Fax: 215.573.3418 \\ Email: pre@wharton.upenn.edu \\ http://www.pensionresearchcouncil.org
}

\begin{abstract}
Opinions expressed here are the authors' own and not necessarily those of institution with which they are affiliated. They thank Eric French, Allen Jacobson, Olivia S. Mitchell, Michael Orszag, Mark Ruloff, and participants at the $13^{\text {th }}$ International Conference on Computing in Economics and Finance for useful comments and Ben Weitzer for research assistance. We are especially grateful to Eric French for his generous sharing of coefficient estimates. A longer version of the paper, including figures for the sensitivity tests, is available from the authors upon request. All findings, interpretations, and conclusions of this paper represent the views of the author(s) and not those of the Wharton School or the Pension Research Council. (C) 2008 Pension Research Council of the Wharton School of the University of Pennsylvania. All rights reserved.
\end{abstract}




\title{
Optimizing the Equity-Bond-Annuity Portfolio in Retirement: The Impact of Uncertain Health Expenses
}

\author{
Gaobo Pang and Mark Warshawsky
}

March 2008

\begin{abstract}
$\underline{\text { Abstract }}$
This paper derives optimal equity-bond-annuity asset portfolios for households in the retirement phase who, with or without a bequest motive, face stochastic capital market returns, have differential exposures to mortality risk and uncertain uninsured health expenses, and have differential Social Security and defined benefit pension coverage. The numerical results show that the presence of health spending risk drives households to shift their portfolios from risky equities to safer assets and works to enhance the demand for annuities due to their increasingwith-age superiority over bonds as a hedge against life-contingent health spending as well as longevity risks. The safe and higher-return annuities in turn provide a greater leverage for equity investment in the remaining asset portfolios. This health-spending-uncertainty-enhanced optimal annuitization result is compatible with the broader theory about liquidity constraints and precautionary savings.
\end{abstract}

\section{Gaobo Pang}

Senior Research Associate

Watson Wyatt Worldwide

901 N. Glebe Rd | Arlington, VA, 22203

Gaobo.Pang@watsonwyatt.com

Mark Warshawsky

Director of Retirement Research

Watson Wyatt Worldwide

901 N. Glebe Road | Arlington, VA, 22203

Mark.Warshawsky@watsonwyatt.com 


\title{
Optimizing the Equity-Bond-Annuity Portfolio in Retirement: The Impact of Uncertain Health Expenses
}

\author{
Gaobo Pang and Mark Warshawsky
}

With the decline of traditional defined benefit (DB) pension plans in the past two decades, there has been a corresponding shift to defined contribution (DC) plans by many U.S. corporations. The Social Security (SS) system may also have reductions in its scheduled benefit payouts in order to move it to permanent solvency. Because DC plans are typically self-managed by their participants and lack the withdrawal discipline featured in the life annuity distributions of most DB plans and of SS, a legitimate concern arises that many retirees may run out of their DC funds or underconsume given that the length of life is uncertain.

To protect people against this longevity risk, some experts have suggested embedding annuitization as a default or mandatory option into DC plans. Despite the superior nature of annuities as insurance against longevity, however, most retired households have historically shown relatively little interest in voluntarily annuitizing their wealth. Various factors have been cited as the potential explanations to this "annuity puzzle". Among them, uncertain health expenses have recently gained particular attention. The literature has thus far yielded inconclusive findings. Turra and Mitchell (forthcoming) and Sinclair and Smetters (2004) find that uncertain uninsured health expenses and their negative correlation with life expectancy at the age of annuity selection upon retirement reduce the attractiveness of annuities. Davidoff, Brown and Diamond (2005), on the other hand, show that uncertain health expenses, if occurring in late life, may actually increase the demand for annuities.

Our study offers a rich and sensible stochastic lifecycle framework to address all the major risks and choices for households in the retirement phase. Our model assumes that 
annuitization can be made at any age and in any amount, in contrast to a one-time choice of annuitization upon retirement, as analyzed in many previous studies. In addition, we consider jointly the household investment choices of bonds, equities, and annuities. (A fixed life annuity basically represents a class of financial assets with its own unique risk and return features; we model the annuitization decision as essentially a portfolio allocation choice.) Specifically, we set up a lifecycle model for the retirement phase in which households optimize consumption and allocate their financial wealth among stocks, bonds and annuities, in the context of the preexisting annuities such as Social Security and DB pension coverage. Households in the model have differential exposure to mortality risks and uninsured health care costs, in addition to facing stochastic capital market returns. They also do or do not have a bequest motive.

Our key findings and their logic are as follows. The uncertainty in uninsured health expenses generally leads to precautionary savings. As this uncertainty is essentially an addition of risk, rational households should shift their wealth portfolio from risky equities to the riskless bonds to maintain a desired level of overall risk exposure. The simulated optimal equity share in household portfolios is similar to the practices of lifecycle funds in the retirement phase.

Life annuities are as safe, though contingent on survival, as bonds, and provide higher returns than bonds due to the embedded survivorship premium, which increases with age, and eventually they dominate bonds, even with a load, for hedging against longevity risk. The occurrence of health expenses is also life contingent and the expense magnitude increases with age, as empirically observed, which makes the higher-return annuities superior to bonds in also hedging against this health spending risk. Simulations reveal the efficacy of annuities in that existing annuity payouts can be rolled over to finance new annuity purchase so as to skim higher returns and provide greater old-age insurance. Alternatively, households may find it desirable to 
use a life care annuity, an integration of life annuity with long term care insurance, because its payment is increasing with health spending directly.

It is optimal for households to hold the precautionary savings in the equity-bond bundle in the early retirement years prior to any annuitization when the annuity return (considering some load) has not yet exceeded the reference returns on these conventional assets. The shift to annuities, when available and optimal, also provides a greater leverage than do bonds for higherrisk-and-return equity investment in the remaining asset portfolios. The health-spendinguncertainty-enhanced optimal annuitization result is compatible with the broader theory about liquidity constraints and precautionary savings because the relatively low uninsured health costs in the early retirement years are largely buffered by the pre-existing SS and DB coverage.

This paper proceeds, as follows, with a brief literature review, the details of the stochastic lifecycle model, the findings from the simulations (built step by step to the complete model about the effect of uncertain health expenses on equity-bond-annuity choices), and concluding remarks.

\section{Literature Review}

Our work builds on and extends the relevant literature. One strand examines the relationship between health expenses and general household saving behavior. Palumbo (1999) considers the effects of uncertain future health expenses on elderly families' consumption decisions. That study, using a lifecycle model, shows that uncertain health expenses play a potentially important role in generating precautionary saving, which helps explain the slow rates of dissaving among elderly Americans in retirement.

Dynan, Skinner and Zeldes (2004) review the various factors that may potentially explain the differences in saving rates by income groups. They argue that the precautionary saving with 
uncertain health expenses and bequest motives are likely the main driving forces for the nondissaving in old ages and saving variations across income groups. These two saving motives need not be mutually exclusive in that the precautionary savings may end up being part of the bequest eventually left to heirs. In a recent study, de Nardi, French and Jones (2006) find that out-of-pocket health care costs increase quickly with both age and permanent income. People in higher income groups, compared with the low-income households, need to save more because they generally have higher probability of living to very advanced ages (differential mortality) and tend to face larger health expenses (differential out-of-pocket health expenses).

Two recent studies particularly examine the effects of health status and medical expenditures on equity-bond portfolio choices. Feinstein and Lin (2006) show that a prospect of poor health and substantial medical expense may lead the elderly to the more risk-averse investment behavior, i.e. a lower proportion of equity. They also argue that a more risk-tolerant attitude towards a bequest would actually boost risky assets in the portfolio held in later life. Love and Perozek (2007) use a lifecycle model to study the saving decision and portfolio choice for older households. They show that the introduction of age-dependent background risks such as health and medical expenses lowers the optimal portfolio shares of risky assets with age.

Another strand of research considers what factors affect the annuitization choice. These factors have been cited as reasons for the empirically observed lack of voluntary annuitization, though general theories recommend annuities as appealing welfare-improving financial instruments. The seminal work by Yaari (1965) suggests that a full annuitization of retirement wealth is optimal due to the superiority of life annuity in longevity insurance, if the consumer has no bequest motive. Subsequent studies have explored various directions. Milevsky and Young (2002) argue that there exists a real option value to initially consume and defer 
annuitization to an older age because the waiting time gives retirees, if sufficiently risk tolerant, opportunities to gain from higher equity returns, better assessment of the length of one's future lifespan, and more favorable terms on annuity purchase. Kotlikoff and Spivak (1981) and Brown and Poterba (2003) show that the risk pooling within a family reduces the benefit of (joint) annuitization for married couples. Dushi and Webb (2004) show that the high levels of preexisting annuities in retirement phase significantly reduce the need to annuitize further.

Particularly relevant are the studies about whether uncertain health expenses reduce or enhance the demand for annuities. Turra and Mitchell (forthcoming) study how health status (difference in survival) and out-of-pocket health expenditures influence the annuity valuation and the optimal level of annuitization at retirement age 65. They find that uninsured health expenditures motivate precautionary savings. This need for liquidity makes annuities less attractive, especially for those in poor health with their life expectancy shortened by health shocks. They also show, however, that the optimal fraction of wealth annuitized in most situations remains large, despite the presence of the uncertain expenditures. Sinclair and Smetters (2004) share the same view - annuities become less effective in providing financial security when health shocks cause large uninsured expenses and simultaneously shorten life expectancy.

Davidoff, Brown and Diamond (2005) recently showed that the sufficient conditions for a full or partial annuitization are much less restrictive than those assumed by Yaari (1965). In particular, people without a bequest motive should annuitize fully their wealth under market completeness, so long as a positive premium exists, comparing the annuity return (with mortality credit incorporated) to the return on the reference conventional asset. Significant, though partial, annuitization remains optimal widely even with the presence of market incompleteness or a bequest motive. Moreover, they argue that the impact of uninsured health expenses on the 
demand for annuities is critically dependent on the timing of such expenses. Uncertain health expenses, when occurring early in retirement, call for more liquidity holdings and less (illiquid) annuities, but will make annuities better financial instruments to hedge against such expenses if they occur late in life.

Researchers have recently devoted more effort to integrating equity-bond allocation choices with annuitization decisions. This direction of research addresses the needs and strategies for retirees in the wealth decumulation phase. Studies by Dus et al. (2005), Horneff et al. $(2006,2006,2007,2008)$, and Maurer et al. (2008) in particular examine various investment portfolios and wealth withdrawal strategies in a lifecycle framework, quantify welfare gains with the addition of fixed or variable annuities, and generally show that a well designed equity-bondannuity retirement portfolio will offer retirees the chance to capture the equity premium when younger and exploit the longevity insurance and mortality credit in later life. These studies, however, do not address the impact of uninsured health expenses on asset allocation and annuitization choices, which are considered particularly in our analysis.

\section{A Lifecycle Model Starting at Retirement}

Preferences. We set up a discrete-time lifecycle model in retirement with age $t \in\{0, \ldots T\}$, where $t=0$ indicates the retirement age and $\mathrm{T}$ the maximum lifespan. Households in the model are assumed to have Epstein-Zin-Weil-type preferences (Epstein-Zin (1989), Weil (1990)) defined over consumption, and a bequest where applicable. Let $\widetilde{C}_{i t}$ denote the utility-generating composite consumption adjusted by household size $n_{t}$ (see below) and $M_{i t}$ is the non-annuitized wealth for household $i$ at time $t$. The Epstein-Zin-Weil preferences are specifically described by the following recursion: 


$$
V_{i t}=\left\{(1-\beta) n_{t} \widetilde{C}_{i t}^{1-1 / \gamma}+\beta\left[E_{t}\left(\phi_{i t} V_{i t+1}^{1-\rho}+\left(1-\phi_{i t}\right) b\left(M_{i t+1} / b\right)^{1-\rho}\right)\right]^{1-1 / \gamma}\right\}^{\frac{1}{1-1 / \gamma}}
$$

where $V_{i t}$ is the indirect utility value at $t, E_{t}$ the expectation operator, $\beta$ the time preference discount factor, $\phi_{i t}$ the year-to-year survival probabilities for person $i$ to age $t+1$ conditional on being alive at age $t$ (see the exposition of differential mortality below), $b$ the strength of bequest motive with $M_{i t+1}$ being the terminal wealth given as a bequest upon death, $\gamma$ the elasticity of intertemporal substitution (EIS), and $\rho$ the coefficient of relative risk aversion (RRA).

Households gain utility from ordinary consumption $C_{i t} / n_{t}$, where household size $n_{t}$ is used to make the measure on a per capita basis. A certain level of consumption is required on necessities $C_{0}$. Households are also assumed to get partial utility through spending on health care on the presumptions that these expenses to some degree reflect endogenous choice and that they include some basic living expenses (as in nursing home expenditures) and some life improving and enhancing activities. Specifically, the composite consumption $\widetilde{C}_{i t}$ in equation is defined as

$$
\widetilde{C}_{i t}=C_{i t} / n_{t}-C_{0}+\kappa_{t} H_{i t}
$$

where $H_{i t}$ denotes the stochastic out-of-pocket health care cost for household $i$ at age $t$, and $\kappa_{t}$ is the age-varying fraction of $H_{i t}$ that yields utility.

Differential Mortality and Uncertain Health Expenses. The relevant literature documents that there exists substantial heterogeneity in mortality rates and uninsured health expenses among individuals, notably by gender, health status, and permanent income, among other factors. To restrain the complexity of computation, we model the heterogeneity mainly across permanent income levels. Specifically, the modeling is based on the recent findings by de Nardi, French and Jones (2006). They show that rich people tend to live longer than poor people and that uninsured 
health expenses rise quickly with both age and permanent income. To avoid tracking the transition of health status, we take the average mortality rates and health expenses estimated by de Nardi, French and Jones (2006) across healthy and unhealthy people for each permanent income group. The implicit assumption here is that the levels of uninsured health expenses do not endogenously alter survival probabilities in the model.

Specifically, the conditional survival probability embedded in the consumer preferences in equation (1), $\phi_{i t}$, is defined as a function of age $t$ and permanent income decile $z_{i}$, that is, $\phi_{i t}=g\left(t, z_{i}\right)$. The dynamics of the stochastic out-of-pocket health care cost, $H_{i t}$, are given by:

$$
\begin{aligned}
& H_{i t}=\exp \left(f\left(t, z_{i}\right)\right) P_{i t} \varepsilon_{i t} \\
& P_{i t}=P_{i t-1} \eta_{i t}
\end{aligned}
$$

where the deterministic component $f\left(t, z_{i}\right)$ is a function of age $t$ and permanent income decile $z_{i}$. The stochastic component $P_{i t}$ represents a permanent shock with innovation $\eta_{i t}$, and $\varepsilon_{i t}$ is a transitory shock. The logarithms of $\eta_{i t}$, and $\varepsilon_{i t}$ are assumed to be independent and identically normally distributed with means zero and variances $\sigma_{\eta}^{2}$ and $\sigma_{\varepsilon}^{2}$, respectively.

Financial Assets. Households in the model face a constant investment opportunity set containing riskless bonds, risky stocks, and safe but life-contingent annuities. The riskless bonds yield a constant real gross return, $R^{b}$, while the return on the risky stocks, $R_{i t}^{e}$, follows a log normal distribution with mean $\bar{R}^{e}$ and variance $\sigma_{e}^{2}$. Hence, the investment return $R_{i t}$ on nonannuitized wealth is a function of the individual's equity-bond portfolio. Specifically,

$$
R_{i t+1}=\alpha_{i t} R_{i t+1}^{e}+\left(1-\alpha_{i t}\right) R^{b}
$$

where $\alpha_{i t}$ is the share of equity investment and $\left(1-\alpha_{i t}\right)$ the remaining share held in bonds. 
We consider single premium immediate annuities with constant real lifetime payouts. For ease of computation, our model only considers the decision of households who purchase joint and survivor life annuities whereby the surviving spouse receives as much as the couple receives when both members are alive. That is, the same fixed level of annuity payout continues from the annuity purchase time until the death of the last surviving spouse. Let $\ddot{a}_{t}$ denote the annuity factor for a household of husband and wife both aged $t$; the purchase with a single premium $W_{i t}$ at $t$ yields an annual annuity payout $W_{i t} / \ddot{a}_{t}$ starting at $t+1$. The annuity factor in turn is determined by assumptions regarding the joint survival probabilities of husband and wife among all annuitants, denoted as $\phi_{t}$, the expense factor, denoted as $v$, and the investment return on underlying assets, assumed constant and denoted as $R_{a}$. Specifically, the uniform-pricing annuity factor is given by

$$
\ddot{a}_{t}=(1+v) \sum_{k=1}^{T}\left(\prod_{j=t}^{t+k} \phi_{j}\right) R_{a}^{-k} .
$$

Let $S_{i t}$ denote the annual payout of annuities "purchased" prior to period $t$, with $S_{i 0}$ corresponding to the pre-existing Social Security and DB payouts, both calculated in real terms. Then, next period annuity payout $S_{i t+1}$ is equal to current annuity $S_{i t}$ plus payout from newly purchased annuity, as follows:

$$
S_{i t+1}=S_{i t}+W_{i t} / \ddot{a}_{t}
$$

Budget Constraints and Wealth Dynamics. Households upon retirement in the model possess certain levels of pre-annuitized wealth (PAW) and non-annuitized wealth (NAW). The former refers to wealth from Social Security and traditional DB pensions, which provide a guaranteed income stream of fixed annual payouts to the household until both members die. The latter broadly refers to the financial wealth accumulated in the working years that can be freely 
invested in stocks, bonds or voluntary life annuities. Both PAW (annual payouts) and NAW can be used to support consumption, pay health care costs, and purchase additional life annuity payouts when desirable. Specifically, the dynamics of financial wealth is defined by:

$$
M_{i t+1}=R_{i t+1}\left(S_{i t}+M_{i t}-H_{i t}-C_{i t}-W_{i t}\right)
$$

and

$$
M_{i t} \geq 0, \forall t
$$

The budget constraint (8) states that annuity payout plus NAW, $S_{i t}+M_{i t}$, forms the "cash-onhand" to cover uninsured health expenses, $H_{i t}$, after which consumption and annuity purchase can be financed in the amounts of $C_{i t}$ and $W_{i t}$, respectively. Alternatively, the individual can hold assets in equities or bonds with $R_{i t}$ being the gross return on the investment portfolio. The simple liquidity constraint (9) mandates that consumers cannot borrow against future SS or DB payouts or die with debt in any period.

The Optimization Problem and Solution Method. The consumer's problem is to choose optimal consumption streams and wealth distributions so as to maximize expected lifetime utility in equations (1) and (2) in a dynamic and recursive pattern, subject to constraints (3) through (9). The set of state variables constraining decisions are $\left(S_{i t}, M_{i t}, P_{i t}, t\right)$ at age $t$. As the number of state variables grows, the required computation increases exponentially, a numerical burden called the "curse of dimensionality". To partially mitigate this problem, following the strategy in Gomes and Michaelides (2005), Carroll (2006), and Horneff, Maurer and Stamos (2006), we exploit the scale-independence of the maximization problem and rewrite all variables using lower case letters as ratios of permanent shocks (i.e., $m_{i t}=M_{i t} / P_{i t}$ ). That is, dividing equations 
above by $P_{i t}$ and using the relation $P_{i t+1} / P_{i t}=\eta_{i t+1}$, it follows that the utility maximization problem, now given the state variables $\left(s_{i t}, m_{i t}, t\right)$, can be rewritten as:

$$
\begin{aligned}
& v_{i t}=\left\{(1-\beta) n_{t} \widetilde{c}_{i t}^{1-1 / \gamma}+\beta\left[E_{t}\left(\phi_{i t} v_{i t+1}^{1-\rho}+\left(1-\phi_{i t}\right) b\left(m_{i t+1} / b\right)^{1-\rho}\right) \eta_{i t+1}^{1-\rho}\right]^{1-1 / \gamma}\right\}^{\frac{1}{1-1 / \gamma}} \\
& \text { s.t. } \\
& \widetilde{c}_{i t}=c_{i t} / n_{t}-c_{0}+\kappa_{t} h_{i t} \\
& m_{i t+1}=R_{i t+1}\left(s_{i t}+m_{i t}-h_{i t}-c_{i t}-w_{i t}\right) \eta_{i t+1}^{-1} \\
& m_{i t} \geq 0, \forall t \\
& h_{i t}=\exp \left(f\left(t, z_{i}\right)\right) \varepsilon_{i t} \\
& s_{i t+1}=\left(s_{i t}+w_{i t} / \ddot{a}_{t}\right) \eta_{i t+1}^{-1} .
\end{aligned}
$$

As no analytical solution to the model exists, a numerical solution method is used. The computation begins by discretizing the continuous state variables $\left(s_{i t}\right.$ and $\left.m_{i t}\right)$. The maximization problem is then solved from the last period backward to the first period for all possible combinations of state grid points and realizations of random variables (equity returns, mortality, and out-of-pocket health expenses). Given the optimal decision rules recorded along this backward process, a large number of Monte Carlo simulations are finally carried out to generate the optimal actions (consumption, asset allocation, and annuity purchase) for consumers from the first period forward to the last period of the lifecycle.

Parameter Calibration. For the numerical solution and simulations, we need to set the parameter values in the model. The value of the subjective discount factor, $\beta$, has been usually taken to be less than unity to reflect impatience, although some studies also suggest the possibility of larger values. We set $\beta$ to 0.96 , a value used by Gomes and Michaelides (2005) and 
Scholz, Seshadri and Khitatrakun (2006), among others. There is a wide range of empirical estimates for the coefficient of relative risk aversion. Within the plausible range, we set $\rho$ to 5 , reflecting a moderate to low risk tolerance for retired households. The elasticity of intertemporal substitution, $\gamma$, is set to 0.5 , also commonly used in the literature. We later conduct sensitivity tests on several key parameters.

As a bequest motive is often cited as one of the major reasons for the dearth of voluntary annuitization, our analysis considers individuals with $b=0$ and $b=2$, separately. The former indicates no bequest, while the latter means a certain strength of the bequest motive, as in Gomes and Michaelides, (2005) and Horneff, Maurer and Stamos (2006). Abel and Warshawsky (1988), however, show that the bequest given in the model depends not only on the value of the bequest strength parameter, $b$, in this general specification, but also on other parameter values in the modeled consumer preferences. More specifically, a higher value of $b$ is needed for a higher level of risk aversion to produce the same desired bequest amount. They also show that $b$ is of a substantial magnitude in many simulation cases. Here, we simply introduce a certain level of bequest motive and make no effort to test which value is correct or most justified.

The distributions of asset returns are based on Watson Wyatt January 2007 U.S. Asset Return Assumptions, which are in turn derived through a blend of economic theory, historical analysis and the views of investment managers. Specifically, the real net bond return, $R^{b}-1$, is set to 3.0 percent; the real net equity return, $R_{t}^{e}-1$, is assumed to have a yearly mean of 6.5 percent and a standard deviation of 16.1 percent. Similar distributions can be found from Shiller (2005) based on long-term government bonds and stock returns of S\&P Composite Stock Price Index for the historical period of 1961-2004. 
We assume that 90 percent of the funds underlying the life annuity are invested in bonds and the remaining 10 percent in equity earning the average equity return. That is, the annuity discount factor is $R_{a}=.9 \times R^{b}+.1 \times \bar{R}^{e}$. In addition, the annuity expense factor (load), $v$, is assumed to be 15 percent. These assumptions are largely consistent with current insurance law and market practice.

For simplicity, all households in our lifecycle model retire at $t=0$ and die at $T=35$, if not earlier. These numbers correspond to ages 65 and 100, respectively. ${ }^{1}$ The household size $n_{t}$, estimated on the Health and Retirement Study, starts with 1.7 at age 65 and declines to 1.1 at age 100. The utility-generating fraction of heath expenses, $\kappa_{t}$, is assumed to increase linearly from 50 percent at age 65 to 80 percent at age 100. The minimum required consumption on necessities, $C_{0}$, is assumed to be $\$ 8,000, \$ 10,000$ and $\$ 12,000$ for the second, fifth and eighth income deciles, respectively.

In this analysis, we make no attempt to test or fit our model to empirically observed annuitization behavior. This is left for future research. Nevertheless, for the purpose of illustration, we run the simulations based on actual wealth distributions among retiring households. Specifically, we tabulate the composition of wealth for households from all of the survey waves of the Health and Retirement Study, if the head of household is aged 65 (or 66 if he/she turned 65 before the survey). Table 1 shows the average wealth in real terms by household income deciles. The non-annuitized wealth includes financial wealth, half of housing equity, and all of IRA balances and DC account values. The pre-annuitized wealth refers to the present discounted value of SS and DB benefits, both calculated in real terms. It is apparent that there are significant wealth differentials across income deciles. The top decile's total wealth is nearly five times larger than the bottom decile's. More importantly, most deciles already have 
their wealth highly annuitized, though not necessarily by voluntary choice. The first decile has over 70 percent of all wealth in Social Security and DB plans, and the ninth and tenth deciles are the only two groups who have wealth less than half annuitized. This high degree of annuitization, as argued in Dushi and Webb (2004), could reduce greatly household need to further annuitize, especially when there is liquidity demand and/or a bequest motive.

\section{Table 1 Here}

The household survival probabilities, which are used by the life annuity provider to calculate the annuity factor in equation (6), are based on the Cohort Life Tables for the Social Security Area (Bell and Miller, 2005). That is, we assume that all annuity purchasers face a uniform pricing, irrespective of their income groups and differential mortalities. A certain degree of adverse selection may thus arise by this assumption, which is included, in reduced form, in the expense factor. The survival rates in equation (1) for the utility-maximizing households, however, are the differential mortalities constructed by de Nardi, French and Jones (2006). They show that people have heterogeneous life expectancies across gender and income groups. For consistency, these differential mortalities are normalized by the above SSA life tables. Further, based on these normalized mortalities for males and females, we construct the differential joint survival rates for households by permanent income deciles. Figure 1a shows the joint unconditional survival rates for the eighth, fifth and second deciles, respectively. Almost all households survive in their late $60 \mathrm{~s}$ and converge to death in their late $90 \mathrm{~s}$. The differences in survival peak in the 80 s. For instance, the expected survival probability at age 87 is 62 percent for the eighth decile households, 54 percent for the fifth decile, and only 48 percent for the second decile.

Figure 1 here 
We use the findings by de Nardi, French, and Jones (2006) to gauge the distribution and dynamics of out-of-pocket health care expenses. These expenses include payments for insurance premiums, nursing home care, hospital, doctor/dental/surgery, prescriptions, and outpatient care, etc. Based on the Assets and Health Dynamics of the Oldest Old (AHEAD) dataset, the authors find that people are subject to heterogeneous out-of-pocket health expenses that rise quickly with both age and permanent income. We make two parsimonious adjustments to their estimates: one, because their study only covers ages 70 through 100, we apply their estimated coefficients for age 70 to ages 65-69 in our model; the other, we multiply the average of male and female health expenses by the household size $n_{t}$. This household size is intrinsically linked to the joint mortality of husband and wife in this later phase of life. When a household member deceases, the household size shrinks and so do the health expenses.

Figure $1 \mathrm{~b}$ shows the average out-of-pocket health expenses for the eighth, fifth and second deciles, respectively. Households with higher permanent income tend to face steeper upward-sloping trajectories of health expenses. For instance, the average out-of-pocket health cost is below $\$ 4,000$ in the 60 s for all households in these deciles and it increases rapidly to over $\$ 40,000$ at the advanced age 100 for the eighth decile, modestly to over $\$ 15,000$ for the fifth decile and slowly to around $\$ 5,000$ for the second decile, conditional on survival. These differences may reflect the fact that the quantity and cost of health care are to some extent a choice. Also, presumably the existence of Medicaid as a welfare health care and long-term care insurance plan explains the lower out-of-pocket health expenses for those with limited income.

It is useful to examine more deeply several aspects of the pattern and magnitude of the uncertain uninsured health expenses, as shown in Table 2. First, average health expenses are larger for the well-to-do (with higher permanent income) - the simulated yearly health expenses 
over ages 65 to 100 are approximately $\$ 4,100, \$ 6,500$ and $\$ 9,100$, respectively, for households in the second, fifth and eighth income deciles. Second, despite the differential dollar values of out-of-pocket costs, the wealthier on average are faced with similar burden of the uncertain health expenses compared to the less wealthy. This point becomes clear when the average health expenses are expressed as a share of pre-existing annuity payouts. Row 3 of Table 2 shows the annual annuity payouts corresponding to the pre-annuitized SS and DB wealth in row 2 of Table 1. ${ }^{2}$ Row 4 of Table 2 reveals that the average health expense accounts for a similar fractionaround 30 percent - of annuity payout for all income deciles. Third, the magnitudes of variations in health expenses grow with permanent income - for instance, the standard deviation of health expenses is $\$ 12,500$ for the eighth decile, more than triple the $\$ 4,100$ standard deviation for the second decile. Taking into account these variations, the health-expense-to-annuity ratio gets much higher, and more so for the wealthier with age. A health care cost equivalent to the yearly average plus two standard deviations, which is a range that approximately 95 percent of possible outcomes fall within, would take up a substantially larger share of disposable wealth across the board. An important implication follows: the uncertainty (volatility) of the health care costs may have a greater influence on consumer behavior than does the expected cost level, as will be revealed in the simulations below.

\section{Table 2 here}

Expressing health expenses as a fraction of pre-existing annuities also serves as a useful double check of the validity of the cost distributions constructed here. Turra and Mitchell (forthcoming) document that the out-of-pocket health expenses took up less than 25 percent of annual Social Security income for the majority of the individuals who were aged 65 and older in the Health and Retirement Study (for survey years 1998 and 2000), while the expenses more than 
exhausted all annual Social Security benefits for about 5.5 percent of the elderly surveyed. Our modeling shows comparable spending percentages of both SS and DB incomes and is thus a sufficient reflection of the impact of health expenses.

Table 2 Here

Simulation Results

We run a large number of simulations $-100,000$ for each income decile - with initial non-annuitized and pre-annuitized wealth as reported in Table 1.

Consumption and Wealth Profiles without Health Expenses and Annuities. Before presenting the results of the complete model, it is useful to show how consumers optimally allocate their financial wealth between consumption in current period and savings for the future, assuming they are shut out of the annuity market and are immune to the uncertain health expenses. They can invest in equities and bonds.

Figure 2 shows the average optimal consumption by income decile. Absent annuities and a bequest motive, consumption in retirement generally declines with age. This is mainly because consumers prefer to consume sooner rather than later as the marginal utility of consumption shrinks fast with higher effective discount rate (higher mortality rate) as consumers age. The consumption in the last period is boosted because uncertainty (at the end) of life is resolved and no wealth should be saved. ${ }^{3}$ The pace of wealth depletion varies across income deciles, faster for the lower income deciles, as indicated by dashed lines in Figure 3. This simply reflects that the top income deciles have more NAW to begin with and, more importantly, they need to save for future consumption because they have a higher probability to survive to very advanced ages.

The presence of bequest motive alters the consumption and wealth profiles, given the same initial wealth. Figure 2 shows that consumers who care about their children choose to 
depress to some degree their consumption in the early years of retirement. As the wealth stock is nontrivial, the additional wealth generated through equity-bond investment can somewhat lift consumption in later years to a similar or even higher level than without bequest. Figure 3 shows that households with more wealth tend to leave greater bequest in dollar terms upon death.

\section{Figures 2 and 3 here}

Figure 4 shows the simulated average equity holdings as a fraction of the non-annuitized wealth by income deciles. The optimal equity-bond portfolio is a function of a host of factors. First, it is optimal for risk-averse households to utilize a certain level of equity investment to enhance wealth creation and the equity fraction varies with their risk tolerance. As demonstrated in the "equity premium puzzle" literature pioneered by Mehra and Prescott (1985), the much higher expected equity return should induce households to invest substantially in equities. Of course, various psychological hurdles or transaction costs in the real world may limit equity investment for some households. Nevertheless, the Survey of Consumer Finances 2004 shows that equity holdings are substantial for households aged 65 and above. The equity investment for the second, fifth and eighth deciles, respectively, accounts for approximately 25 percent, 50 percent and more than 90 percent of their DC and IRA wealth.

\section{Figure 4 here}

Second, the relative position of risk-free pre-existing annuities alters the optimal equitybond split. This can be seen in the case of no bequest motive in Figure 4: as NAW is being depleted with age and the pre-existing annuities form a greater proportion of total wealth, households choose a larger equity fraction in NAW. This portfolio move is not necessarily imposing more risk in the context of increasing portion of safe annuity. At the end of life, it is in their interest to consume all wealth. Third, the requirement of minimum consumption on 
necessities induces a portfolio tilt towards bonds. Absent such consumption floors, the optimal NAW equity fractions would be higher for all income deciles. With these consumption floors, which are assumed in the model to be lower for households with lower income, the optimal household portfolios are more in line with the empirical pattern. And fourth, the equity-bond allocation is dependent on households' preferences towards bequest. The NAW equity share is generally lower when a bequest motive exists. Apparently, the larger NAW balances for a potential bequest make the annuity leverage relatively smaller, which mandates a lower NAW equity fraction for the same level of overall risk exposure. Also, the equity share declines slightly with age to limit the risk exposure of the bequest as households shift utility weight from consumption to a bequest. The reason for the risk-averse households with a bequest motive to be more cautious is that the uncertainty associated with stochastic equity returns adds randomness to the size of bequest as well as to consumption. This pattern of equity holdings is consistent with the findings by Gomes and Michaelides (2005) who show that the presence of a bequest motive decreases the pace at which wealth is drawn down and that a stronger bequest motive decreases the optimal equity holdings.

\section{Wealth and Equity-Bond Portfolio Choices with Uncertain Health Expenses, but without}

Annuities. We now introduce stochastic uninsured health expenses, but continue to assume that consumers have no access to the annuity market. The main objective here is to identify the impact of the addition of the risk on equity-bond portfolio choice. The uninsured health expenses constitute a drain to the disposable wealth, which naturally lowers non-health consumption at all ages (results not shown). More importantly, wealth available for consumption after the deduction of health expenses becomes more volatile. This uncertainty in health expenses leads to precautionary savings. That is, households, who face borrowing constraints in 
a world of incomplete market for lending and insurance, are induced to accumulate or keep a higher level of wealth as a buffer against adverse shocks. The theory about precautionary savings and liquidity constraints has been well developed by Deaton (1991) and Carroll (1992), among others. Consistent with this theory, as shown in Figure 5, households tend to keep a larger stock of wealth on hand with the presence of uncertain health expenses compared with no health shocks. Interestingly, this precautionary motive has a stronger effect on higher-income households because they are faced with a steeper path of more volatile health expenses. In other words, the magnitude of extra buffer savings is more influenced by the volatility and shape of health expenses rather than the average cost level per se.

Figure 5 here

These uninsured health expenses also alter the optimal equity-bond composition of the savings. Given the same consumer preferences, the addition of risk in the form of uncertain health expenses pushes consumers to move assets from risky equities to riskless bonds in order to rebalance to a portfolio consistent with their risk tolerance. Figure 6 shows the impact of the stochastic health expenses on equity holdings as a fraction of non-annuitized wealth, without and with a bequest motive. The simulated results confirm the above conjecture by showing that it is optimal for consumers to hold a smaller fraction of equity in their savings. Moreover, the equity share is flat or declines slightly with age in contrast to the "whale" shape without health spending risk. Also note that the optimal level and shape of the portfolio shares are broadly similar to the practices of lifecycle funds in the retirement phase. The simulated equity fraction with health spending risk, averaged across the second, fifth and eighth deciles for ages 65 through 100, is barely over 40 percent, while the lifecycle funds in the marketplace on average hold about 38 percent of assets in equity for investors at or beyond target retirement age. ${ }^{4}$ 
Figure 6 here

Annuitization Choice with Limited Equity Holding. In this subsection, we mainly explore the annuity choice, given a certain automatic level of equity holdings in NAW, without and with a bequest motive, first without and then with uninsured health expenses. The full optimization over the complete equity-bond-annuity investment set is discussed in next subsection. Annuities are contingent securities in that the annuitant, after paying the irrevocable premium, receives the predetermined annuity payout if she/he is alive and nothing if dead. Bonds and equities are non-lifecontingent asset classes that in theory should deliver average and typically lower returns than the contingent payout. The (annuity) insurance providers pool both the annuity funds and the mortality risks among the annuitants. When some annuitants die, their funds are allocated to those alive in the pool. This extra asset redistribution forms the mortality credit or survivorship premium which grows with age.

The trajectory of the ever-increasing annuity returns becomes clearer if we look at the one-period annuity return implied in equation (6), which is $R_{a} /\left[\phi_{t}(1+v)\right]$ for an age- $t$ annuitant. As the survival rate, $\phi_{t}$, gets smaller as people age, this annuity return increases nonlinearly. That is, the older the annuitants who outlive others are, the greater are the survivorship bonuses. With the expense load, $v$, being within a range that allows the existence of the annuity business, this yearly annuity return will first exceed the return on bonds and then eventually the expected return on equities.

This illustrates the ultimate superiority of life annuities as longevity insurance over bonds and equities. As Davidoff, Brown and Diamond (2005) argue, absent a bequest motive, the sufficient condition for a full annuitization is that the return on annuity is greater than the reference return on conventional assets. This superiority remains valid with the presence of a 
bequest motive. However, because households now want to hold certain wealth in a form that can be bequeathed to their heirs, partial (and still significant) annuitization becomes optimal.

With endogenous annuitization, we here assume that 40 percent of non-annuitized wealth is automatically invested in equities, a rule-of-thumb investment allocation for older households. This somewhat arbitrary percentage is also largely in line with the average equity fraction derived in the above equity-bond optimization. Absent a bequest motive, it is optimal for many households to start annuitizing their wealth in their late 70 s and fully annuitize in their 80 s during the course that the expected annuity return for the remaining lifetime exceeds those on bonds and equities. (The simulated NAW balance is shown in next subsection along with other scenarios.) The corresponding annuity levels for these income deciles are plotted in Figure 7 (solid lines). Note that the rising annuity level after the depletion of NAW is due to new annuity purchases financed by existing annuity payouts. With a bequest motive, households keep substantial NAW on hand. Correspondingly, they reduce voluntary annuity purchases (solid lines in Figure 7, right side). It is in the interest of households to smooth their annuity purchase (as also observed in the case of no bequest) because the wait may bring better annuity return in terms of greater mortality credit but also because the strategy may end up leaving a bigger bequest in the case of death. Quite approximately, this modeled behavior may correspond with reality: most annuities are purchased with guaranteed periods of up to 20 years.

\section{Figure 7 here}

Now we introduce uncertain uninsured health expenses. Interestingly, this translates into greater voluntary annuitization than otherwise, with or without a bequest motive (dashed lines in Figures 7). Several factors contribute to explaining this pattern of change associated with uncertain health expenses. First, uncertain health spending does not alter the dominance of 
annuity returns over the reference returns on bonds and equities beyond certain ages. Second, both annuity payouts and health expenses are life contingent and both annuity returns and health costs are increasing with age. As the addition of health shocks would induce households to shift from risky equities to safer assets, if they could, the annuities that are available here are more compatible and provide higher expected returns than bonds.

Finally, this enhanced annuity demand does not necessarily contradict the precautionary savings theory in the literature. The theory implies basically that health spending uncertainty should lead to the holding of more liquid assets such as bonds instead of the illiquid annuities because later annuity payouts can not be transferred to cover health pitfalls in earlier years. The annuity demand here and this theory can be harmonized in two parts: (i) This liquidity constraint is less likely to be binding in the early retirement years in the context of pre-existing annuities as well as cash. The average health expenses over ages $65-75$ are in the range of $\$ 4,000-5,000$ for the second, fifth and eighth deciles, account for approximately 21 percent (with low volatility), 22 percent and 18 percent of annual SS and DB payouts $(\$ 14,900, \$ 19,800$ and $\$ 27,100)$, respectively, and are thus to a large extent buffered by these pre-existing annuities plus nonannuitized wealth. ${ }^{5}$ The SS and DB payouts also effectively cover the minimum consumption on necessities. As for health expense in later years, the optimal hedging strategy is to annuitize so as to skim the increasing-with-age annuity returns (mortality credit). (ii) Nevertheless, the presence of health spending risk depresses consumption at all ages and motivates risk-averse households to build up more NAW in their 60s and 70s to buffer against adverse shocks. Households would eventually annuitize these precautionary savings, at least partially, when the annuity return is sufficient to outperform bonds and equities, to effectively hedge against future health shocks. Before that time, it is optimal to hold the savings in the equity-bond portfolio. This strategy also 
gives households opportunities to improve their future budget constraint if the associated investment risk is within the tolerable range.

In short, the enhanced annuitization does not necessarily jeopardize the liquidity needs and serves well as an effective insurance against future life-contingent health expenses. ${ }^{6}$ The finding that the uncertain health expenses may turn out to enhance the demand for annuities is consistent with the theoretical conjecture by Davidoff, Brown and Diamond (2005). They argue that the impact of uninsured health expenses on the demand for annuities is critically dependent on the timing of such expenses. That is, uncertain health expenses, when occurring early in retirement, call for more liquidity holdings and less illiquid annuities, but will make annuities a better financial instrument to hedge against health shocks if these expenses occur late in the life.

The modeling of out-of-pocket health expenses in this paper is more sophisticated than in Davidoff, Brown and Diamond (2005) and it is based on the careful empirical study by de Nardi, French and Jones (2005) using the AHEAD surveys. The health spending risk occurs at all ages in our model, and the risk exposure is increasing with age in terms of both the average levels and the volatilities of these expenses across income groups. In this context, a life care annuity (LCA), though not explicitly modeled here, is particularly compatible with this profile of health spending risk and expenses because the LCA payout is increasing with health spending directly. Murtaugh, Spillman and Warshawsky (2001) illustrate in detail that a life care annuity, as an integration of a life annuity and long-term care insurance that provides lifetime income to the named annuitant and automatically hikes the periodic payments in the events of physical impairment or disability, would reduce the cost of both coverages and appeal to diverse populations of varied longevity and morbidity expectations. 
Annuity-Equity-Bond Portfolio Choice with Uncertain Health Expenses. Consumers in the model are now assumed to do a full optimization with access to the complete investment set of annuities, equities and bonds, against the background of the uncertain uninsured health expenses, longevity risk, and stochastic capital market returns, as well as bequest motives. The simulations in the full optimization confirm the major findings in the earlier subsections and also generate important new findings that were not observable in the "limited" optimizations.

It is optimal for households to annuitize their wealth, fully or partially depending on the bequest motive, when the expected annuity return is greater than the reference returns on bonds and equities (compare solid with circled lines in Figure 8). The addition of the background health risk acts to enhance the demand for annuities over bonds. Figure 8 shows that the conversion of liquid precautionary savings to annuities is particularly striking (compare dashed with plus lines). With access to the complete investment set, households have more flexibility when optimizing over their consumption paths and portfolios. As a result, their annuitization process is somewhat smoother than when a fixed percentage of their NAW portfolio was exogenously allocated to equity. The simulated average annuity levels are plotted in Figure 9.

Figures 8 and 9 here

As the safe and higher-return annuities, though life-contingent, account for a larger fraction of total wealth, they have a more powerful leverage to accommodate a higher equity fraction in the NAW. As shown in Figure 10a, the full optimization would allow households, with or without a bequest motive, to invest a larger fraction of their NAW in equity. For instance, the greater leverage allows a hike in equity investment by more than 20 percentage points for the fifth-income-decile households with a bequest motive in the second half of their $70 \mathrm{~s}$, absent 
health costs (compare solid with circled lines in Figure 10a). This hike does not necessarily bring additional risk, given the higher degree of annuitization.

Figure 10 here

In the presence of uncertain uninsured health expenses, this annuity leverage for equity holding is even more pronounced. Were households shut out of the annuity market, they would substantially reduce their equity exposure (dashed lines in Figure 10a). With access to annuities, the fifth decile households, for instance, would increase the NAW equity fraction by more than 30 percentage points in their late-70s (plus line in Figure 10a). The magnitude of equity holding varies across income deciles, but they share a similar pattern. Based on the same results as shown in Figure 10a from the full optimization, Figure 10b re-plots the optimal annuity-bondequity allocations of wealth which now excludes the pre-existing Social Security and defined benefit wealth. This is to make clear the voluntary choices in the decision set of households. Households in the model start purchasing annuities in their 70's (left panel of Figure 10b), eventually fully annuitize absent a bequest motive, or keep a significant amount of wealth and bond allocation if they intend to leave a bequest. The right panel of Figure 10b shows that the health spending risk induces households to initiate the annuitization several years earlier and that the safe asset fraction (annuity plus bonds) becomes higher for all income deciles.

The greater equity investment, with realizations of equity premium, in turn helps support an increasing path of annuity purchase. This phenomenon is particularly observable when households have a bequest motive and thus hold a significant NAW base for investment (compare dash-dotted with dashed lines in Figure 9). The full optimization shows that the annuitization and equity-bond portfolio choices are intertwined together and should be optimized jointly. A life annuity is not just a passive replacement of bonds as an insurance against risk; it is 
also an integral part of the asset allocation strategy for wealth creation because of its effective accommodation of higher-risk-and-return portfolios.

A life annuity apparently improves household welfare; otherwise consumers would simply forgo this option. Figures 8 and 9 to some extent reflect the welfare improvement by the magnitudes of financial assets reshuffled. More directly, the welfare improvement can be measured by the difference between consumption profiles, without and with life annuities, in Figure 11 (compare solid with circled lines for the case of no health expenses and compare dashed with plus lines with stochastic health expenses). Specifically, households enjoy much higher consumptions late in life when supported by annuities, and this welfare improvement is particularly valuable with annuities hedging against life-contingent uninsured health expenses. Figure 11 Here

Sensitivity Tests. We now conduct sensitivity tests (results not plotted). We first change the values of two parameters in the household preferences: a lower elasticity of intertemporal substitution (0.3) and separately a lower relative risk aversion (3.0) versus the above baseline assumptions $(\mathrm{EIS}=0.5, \mathrm{RRA}=5.0)$. All three major uncertainties, i.e., longevity, asset returns, and health costs, are present. EIS reflects households' willingness to substitute consumption over time. A lower value of EIS implies that households are more concerned about the consumption smoothing from year to year, and relatively less concerned about the long run hedging against the longevity and health spending risks. The optimal annuity level is hence lower than in the benchmark case. A lower EIS has little impact on equity allocation in NAW.

The relative risk aversion value (RRA) reflects household attitude towards risk. A lower value of RRA means that they are more risk tolerant, which in turn has two implications. First, households would hold less precautionary savings in their 60 s and early 70 s to buffer against 
adverse shocks and would hold a larger fraction of wealth in equity with the hope of capturing risk premium. Second, the appeal of equity premium mitigates the attractiveness of annuities to the more risk-tolerant households, and hence less wealth is being annuitized in the later years, with or without a bequest motive.

In the context of the ongoing shift from DB pension plans to DC plans and possible reforms of the Social Security system, we conduct a counterfactual experiment in which all DB coverage has been replaced with DC-type plans and the Social Security system has been partially carved out via personal retirement accounts. That is, we assume households have the same level of initial wealth upon retirement as above but all DB wealth and one third of SS wealth is now in the form of cash (non-annuitized wealth) rather than the pre-existing annuities. ${ }^{7}$ All the relevant uncertainties are present.

The simulated optimal annuity profiles are similar in shape to the baseline case, but at lower levels. This level difference is because of the assumption that annuity purchase on the commercial market would face a 15 percent load. In other words, it does not indicate that the pre-existing annuity level is higher than otherwise desirable. In this alternative situation, it is optimal for many households to hold a lower NAW equity fraction compared with the baseline above, given the lower annuity leverage for risky portfolios.

Another sensitivity test is on the annuity expense factor (load). Potential annuity buyers may have private information about their health status and mortality rate. Given uniform annuity pricing, people who find life annuities desirable and buy such annuities tend to be those with longer life expectancy, which makes the life annuity product less profitable from the perspective of insurance providers. So insurance providers impose an annuity load to cover the loss associated with this adverse selection problem in the market. It is possible, however, that this 
adverse selection problem and the annuity load will be reduced with certain new approaches and products. Particularly, as more DC plans set annuitization as a default or voluntary option, a bigger pool of heterogeneous life expectancies may form. Or, as mentioned above, according to the Murtaugh, Spillman and Warshawsky (2001) proposal, an integrated product combining life annuity with long-term-care insurance will probably appeal to a larger population and serve as a market solution to the adverse selection problem. We therefore conduct an alternative experiment assuming a lower expense load -7.5 percent versus the 15 percent in the benchmark.

A lower annuity load has some important implications compared with the benchmark.

First, the year-to-year annuity return would exceed the reference returns on bonds and equities sooner so that retirees would initiate the annuitization several years earlier. Second, given a lower annuity load, a higher annuity level and thus greater leverage for equities, a higher NAW equity fraction becomes optimal. Third, because the same desirable level of annuity now requires a lower premium, more resources could be used to boost consumption or bequest.

\section{Conclusions}

This paper sets up a lifecycle model and derives the optimal equity-bond-annuity portfolios for retired households, who have differential exposure, by income deciles, to mortality and uninsured health spending in addition to the uncertainty in asset returns, in the context of differential Social Security and DB plan coverage. For simplicity, we limit the annuitization choice to the joint and survival annuities whereby the same level of annuity payout continues from the annuity purchase time until the death of the last surviving spouse. With the flexible equity-bond-annuity choices, households would annuitize their wealth, fully or partially depending on their bequest motive. The superiority of annuities in hedging against longevity risk 
is attributable to their eventually higher returns, with mortality credit incorporated, than the reference returns on conventional assets.

Consistent with the literature, uncertainty in health expenses generally leads to precautionary savings and an asset allocation shift from risky equities to riskless bonds, absent annuitization choice. The superiority of annuities over bonds in hedging against longevity risk similarly applies to the hedging against uncertain health expenses because both annuity returns and health expenses are life-contingent and rise with age. As health spending shocks induce a portfolio shift towards safer assets, annuities are more efficient and eventually dominate bonds. This higher degree of annuitization also provides a greater leverage for more equity holdings in asset portfolios, ceteris paribus, without increasing the overall investment risk exposure. In other words, annuitization is not just a passive replacement of bonds as an insurance against risk; it is also an integral part of the asset allocation strategy for wealth creation because it accommodates higher-risk-and-return portfolios.

This health-spending-uncertainty-enhanced annuitization is not contradictory to the theory about liquidity constraints and precautionary savings. On the one hand, the pre-existing annuities such as Social Security and DB payouts to a large extent have served as a buffer against adverse shocks. On the other hand, precautionary savings in the liquid equity-bond bundles are noticeable in the retirement years when bond and equity returns are yet to be dominated by annuities. With the superiority of annuities in hedging against both longevity and health risks, however, households would be better off by eventually using these precautionary savings, at least partially, to purchase more annuities. Life annuities support late-life consumptions and significantly improve household welfare. Admittedly, the attractiveness of annuities may be undermined if the health risks were concentrated and expenses were larger (or 
catastrophic) in the early retirement years than later, in contrast to the empirically observed trajectories, because of the rigidity in annuities that future annuity payouts can not be transferred to finance current expenditure.

Our analysis indicates that households would be better off by annuitizing their retirement wealth in DC plans or IRAs if the decline in DB plans continues or if Social Security is to be (partially) converted to personal accounts. The (offsetting) voluntary annuitization would not only utilize a life annuity's fundamental insurance against longevity risk but also would improve household welfare by concurrently buffering and hedging against other life contingent costs such as health care expenses. This indicates the importance of embedding the annuity feature into DCtype retirement plans if they are to be the mainstream plans. As more DC plans adopt the annuitization option and hence the annuity pool expands, and also as the development of new products such as life annuities integrated with long-term-care insurance helps circumvent market inefficiencies, one may project that there will be increased demand for life annuities. 


\section{References}

Abel, Andrew, and Mark Warshawsky. 1988. "Specification of the Joy of Giving: Insights from Altruism," Review of Economics and Statistics, 70, 145-149.

Bell, Felicitie C. and Michael L. Miller. 2005. "Life Tables for the United States Social Security Area 1900-2100," Social Security Administration Actuarial Study No. 120.

Brown, Jeffrey R. 2003. "Redistribution and Insurance: Mandatory Annuitization with Mortality Heterogeneity," Journal of Risk and Insurance, v70 (1), pp.17-41.

Brown, Jeffrey R. and James M. Poterba. 2000. "Joint Life Annuities and Annuity Demand by Married Couples," Journal of Risk and Insurance, 67 (4), pp. 527-53.

Carroll, Christopher D. 1992. "The Buffer-Stock Theory of Saving: Some Macroeconomic Evidence," Brookings Papers on Economic Activity, 2, 61-156.

Carroll, Christopher D. 2001. "A Theory of the Consumption Function, With and Without Liquidity Constraints," Journal of Economic Perspectives, 15(3), 23-46.

Carroll, Christopher D. 2006. "The Method of Endogenous Gridpoints for Solving Dynamic Stochastic Optimization Problems," Economics Letters, pp. 312-320.

Davidoff, Thomas, Jeffrey R. Brown and Peter A. Diamond. 2005. “Annuities and Individual Welfare," American Economic Review, vol. 95(5), pp. 1573-1590, December.

De Nardi, Mariacristina, Eric French and John Bailey Jones. 2006. "Differential Mortality, Uncertain Medical Expenses, and the Saving of Elderly Singles," NBER Working Paper 12554.

Deaton, Angus S. 1991. "Saving and Liquidity Constraints," Econometrica 59, 1221-1248.

Dus, Ivica, Raimond Maurer, and Olivia S. Mitchell. 2005. "Betting on Death and Capital Markets in Retirement: A Shortfall Risk Analysis of Life Annuities versus Phased Withdrawal Plans," Financial Services Review, Lead article, (14): 169-196.

Dushi, Irena and Anthony Webb. 2004. "Household Annuitization Decisions: Simulations and Empirical Analyses," Journal of Pension Economics and Finance, 3(2): 109-143.

Dynan, Karen E., Jonathan Skinner and Stephen P. Zeldes. 2004. "Do the Rich Save More?" Journal of Political Economy, vol. 112(2), pp. 397-444, April.

Feinstein, Jonathan S. and Ching-Yang Lin. 2006. "Elderly Asset Management," Working Paper, Yale University. 
Gomes, Francisco, and Alexander Michaelides. 2005. "Optimal Lifecycle Asset Allocation: Understanding the Empirical Evidence,” Journal of Finance, vol. LX, no. 2, pp. 869-904.

Horneff, Wolfram J., Raimond Maurer, Olivia S. Mitchell, and Ivica Dus. 2006. “Optimizing the Retirement Portfolio: Asset Allocation, Annuitization, and Risk Aversion,” Pension Research Council (PRC) Working Paper No. 2006-10.

Horneff, Wolfram J., Raimond Maurer, Olivia S. Mitchell, and Ivica Dus. 2008. "Following the Rules: Integrating Asset Allocation and Annuitization in Retirement Portfolios," Insurance: Mathematics and Economics, 42: 396-408.

Horneff, Wolfram J., Raimond Maurer, Olivia S. Mitchell, and Michael Z. Stamos. 2007. "Money in Motion: Dynamic Portfolio Choice in Retirement," Pension Research Council (PRC) Working Paper No. 2007-07.

Horneff, Wolfram J., Raimond Maurer, and Michael Z. Stamos. 2006. "Lifecycle Asset Allocation with Annuity Markets: Is Longevity Insurance a Good Deal?" University of Michigan Retirement Research Center Working Paper No. 2006-146.

Kotlikoff, Laurence and Avia Spivak. 1981. "The Family as an Incomplete Annuities Market," Journal of Political Economy, vol. 89, no. 2, pp. 372-391.

Love, David A. and Maria G. Perozek. 2007. "Should the Old Play It Safe? Portfolio Choice with Uncertain Medical Expenses,” Working Paper, Williams College.

Maurer, Raimond, Christian Schlag and Michael Z. Stamos. 2008. "Optimal Life-Cycle Strategies in the Presence of Interest Rate and Inflation Risk," Pension Research Council (PRC) Working Paper No. 2008-01.

Mehra, Rajnish and Edward C. Prescott. 1985. “The Equity Premium: A Puzzle,” Journal of Monetary Economics 15: 145-161.

Milevsky, Moshe and Virginia R. Young. 2002. "Optimal Asset Allocation and the Real Option to Delay Annuitization: It's Not Now-or-Never,’ Pensions Institute Working Paper 0211 (September).

Murtaugh, Christopher, Brenda Spillman, and Mark Warshawsky. 2001. "In Sickness and In Health: An Annuity Approach to Financing Long-term Care and Retirement Income," Journal of Risk and Insurance, 68(2), pp. 225-254.

Palumbo, Michael G. 1999. "Uncertain Medical Expenses and Precautionary Saving Near the End of the Lifecycle," Review of Economic Studies, vol. 66(2), pp. 395-421, April. 
Scholz, John Karl, Ananth Seshadra and Surachai Khitatrakun. 2006. "Are Americans Saving ‘Optimally’ for Retirement?’ Journal of Political Economy, vol. 114, no. 4, pp. 607-643.

Shiller, Robert. 2005. Irrational Exuberance, 2nd Edition, Princeton University Press, with updated data at www.irrationalexuberance.com.

Sinclair, Sven H. and Kent A. Smetters. 2004. "Health Shocks and the Demand for Annuities," Technical Paper Series 2004-9, Congressional Budget Office.

Turra, Cassio M. and Olivia S. Mitchell. Forthcoming. "The Impact of Health Status and Out-ofPocket Medical Expenditures on Annuity Valuation," In Recalibrating Retirement. Eds. John Ameriks and Olivia S. Mitchell. Oxford University Press.

Weil, Philippe. 1990. "Non-Expected Utility in Macroeconomics,” Quarterly Journal of Economics, 55(1), 29-42.

Yaari, Menahem E. 1965. "Uncertain Lifetime, Life Insurance, and the Theory of the Consumer," Review of Economic Studies, 32, pp.137-150. 
Figure 1 Differential Mortality and Health Expenses by Income Deciles

a. Joint Unconditional Survival Rate
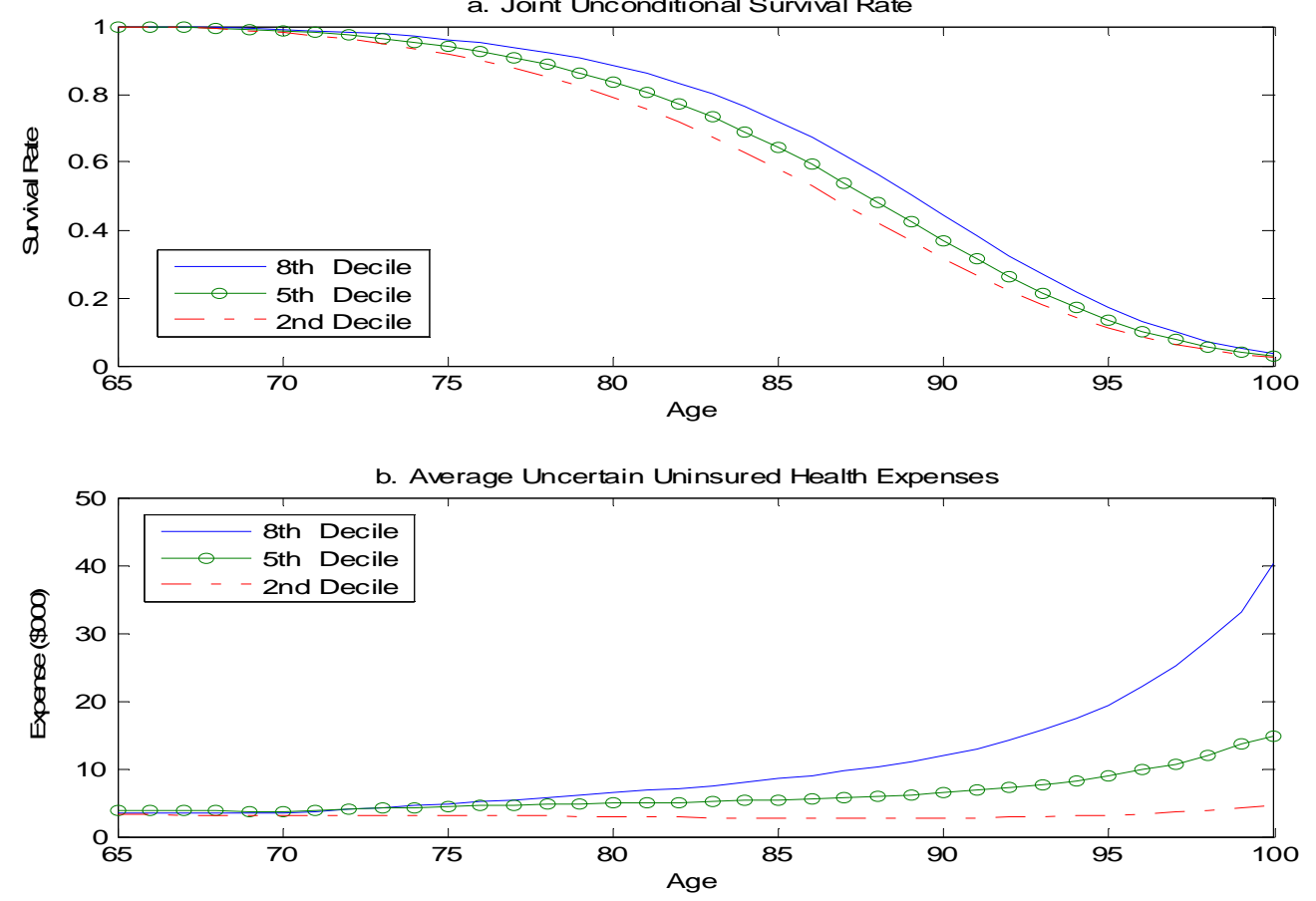

Source: Authors' simulations.

Figure 2 Simulated Average Consumption by Income Deciles

(Equity-bond choice, no annuitization, no health expenses)
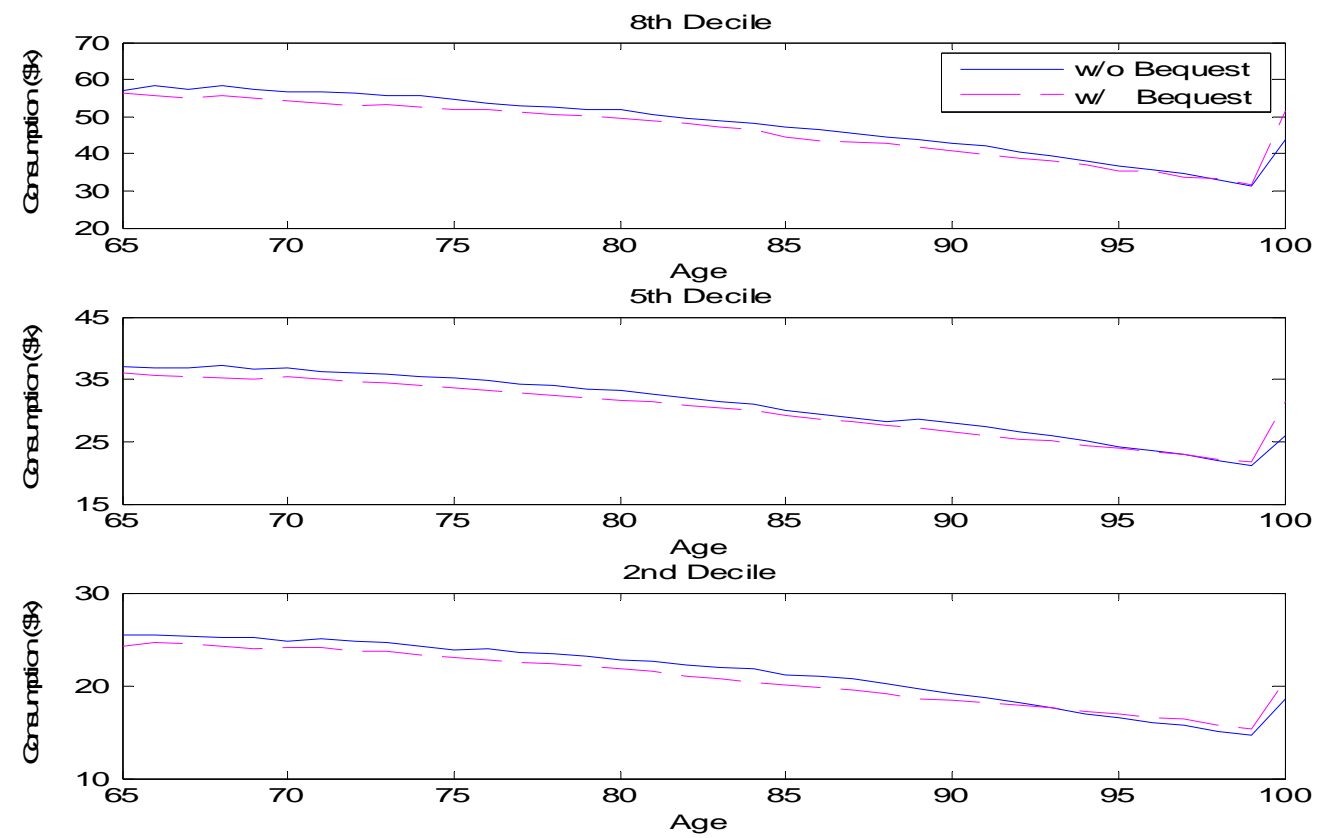

Source: Authors' simulations. 
Figure 3 Simulated "Cash-on-Hand" by Income Deciles

(Equity-bond choice, no annuitization, no health expenses)
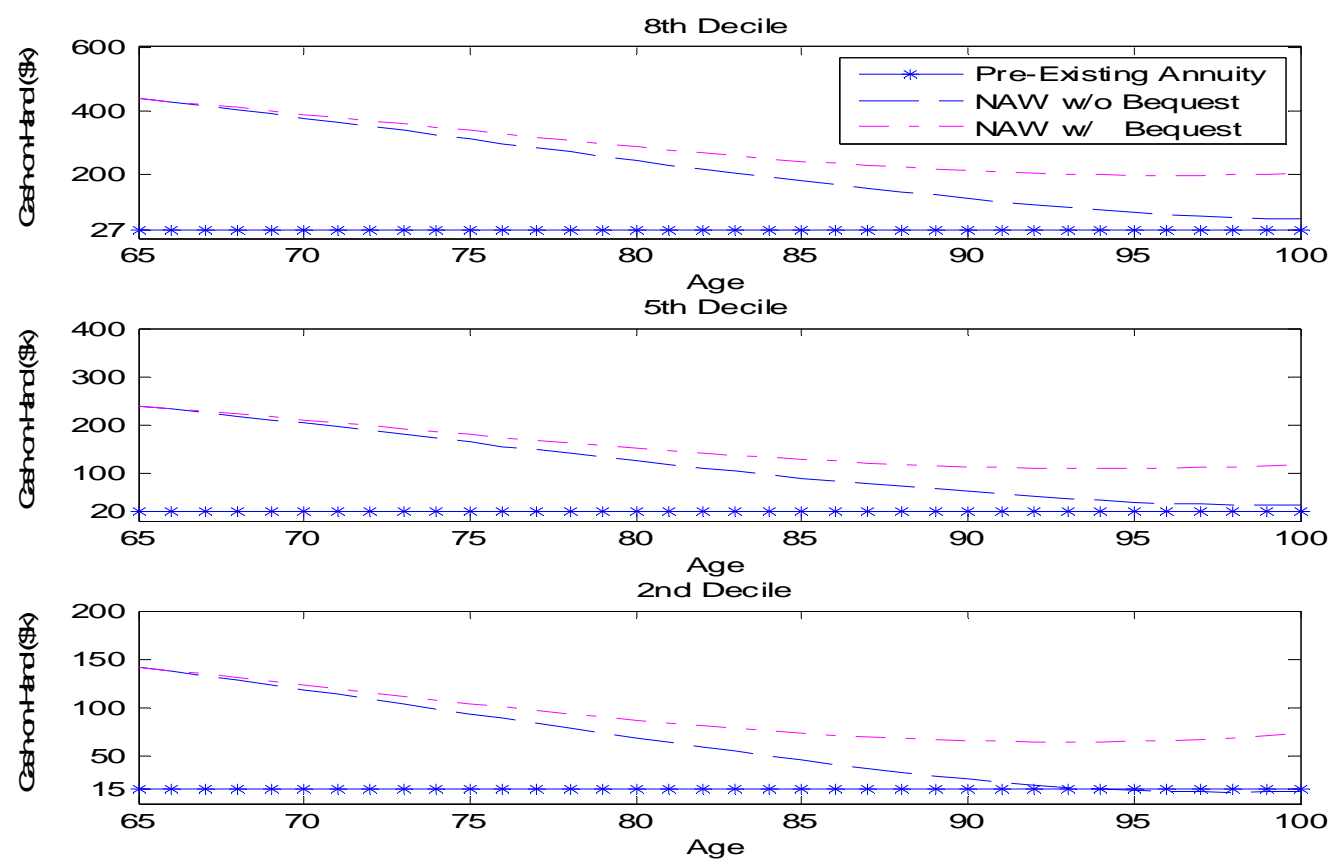

Source: Authors' simulations. 
Figure 4 Optimal Equity Fraction of Non-Annuitized Wealth by Income Deciles (Equity-bond choice, no annuitization, no health expenses)
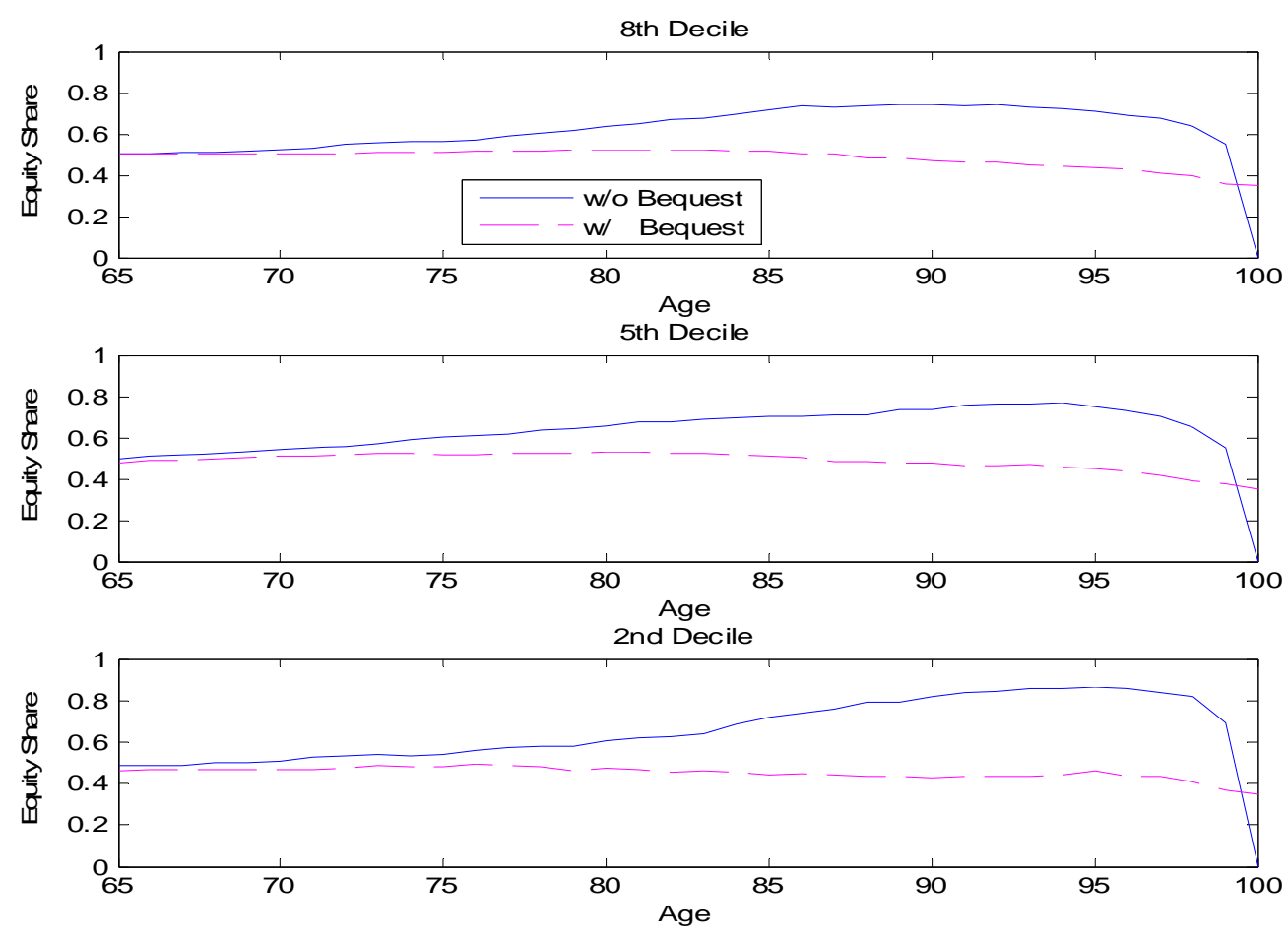

Source: Authors'simulations. 
Figure 5 Non-Annuitized Wealth by Income Deciles

(left - no bequest, right - with bequest motive) (Equity-bond choice, no annuitization)

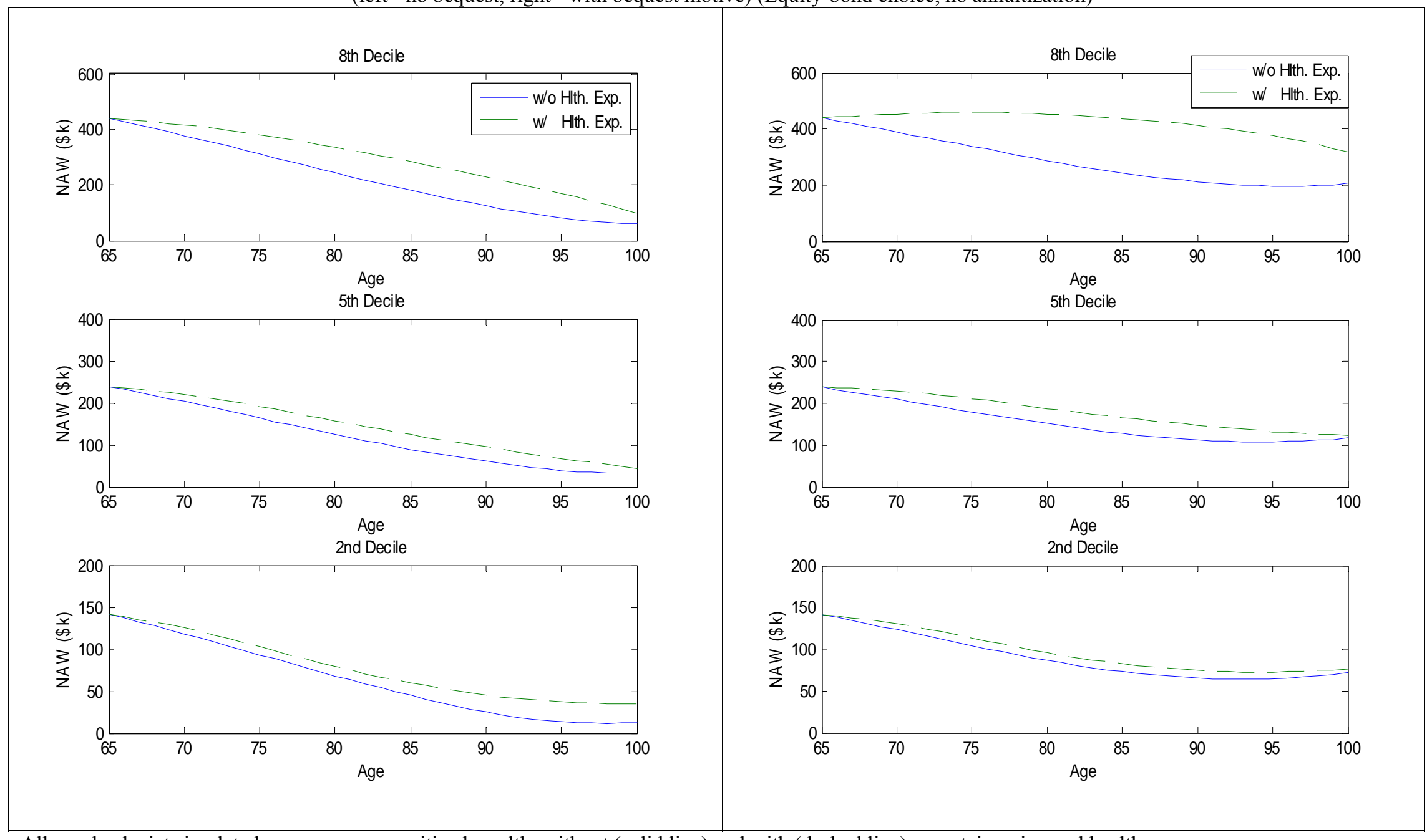

All graphs depict simulated average non-annuitized wealth: without (solid line) and with (dashed line) uncertain uninsured health expenses.

Source: Authors' simulations. 
Figure 6 Equity Fraction of Non-Annuitized Wealth by Income Deciles

(left - no bequest, right - with bequest motive) (Equity-bond choice, no annuitization)

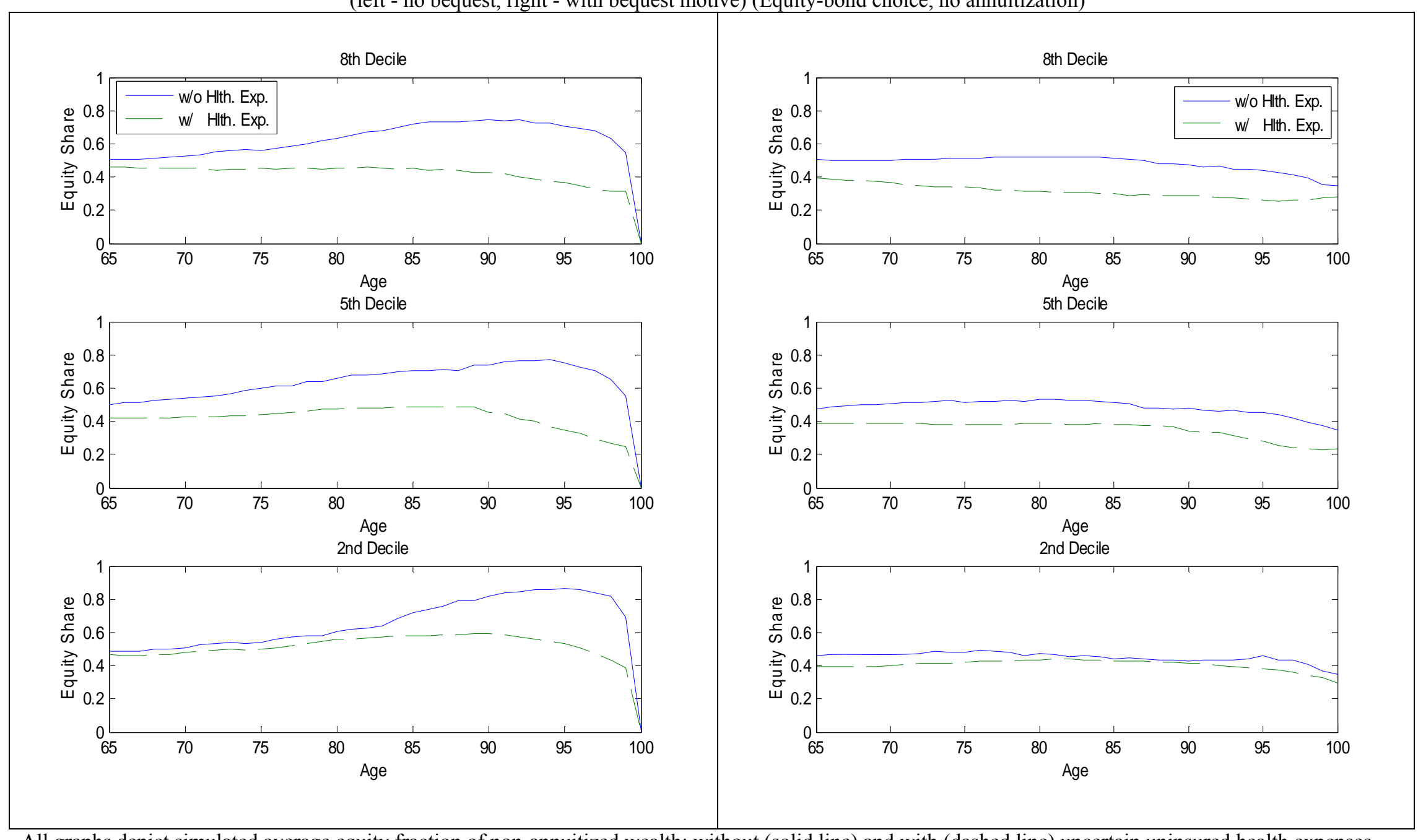

All graphs depict simulated average equity fraction of non-annuitized wealth: without (solid line) and with (dashed line) uncertain uninsured health expenses. Source: Authors' simulations. 
Figure 7 Total Annuity Level by Income Deciles

(left - no bequest, right - with bequest motive) (Annuitization choice, no equity-bond choice)

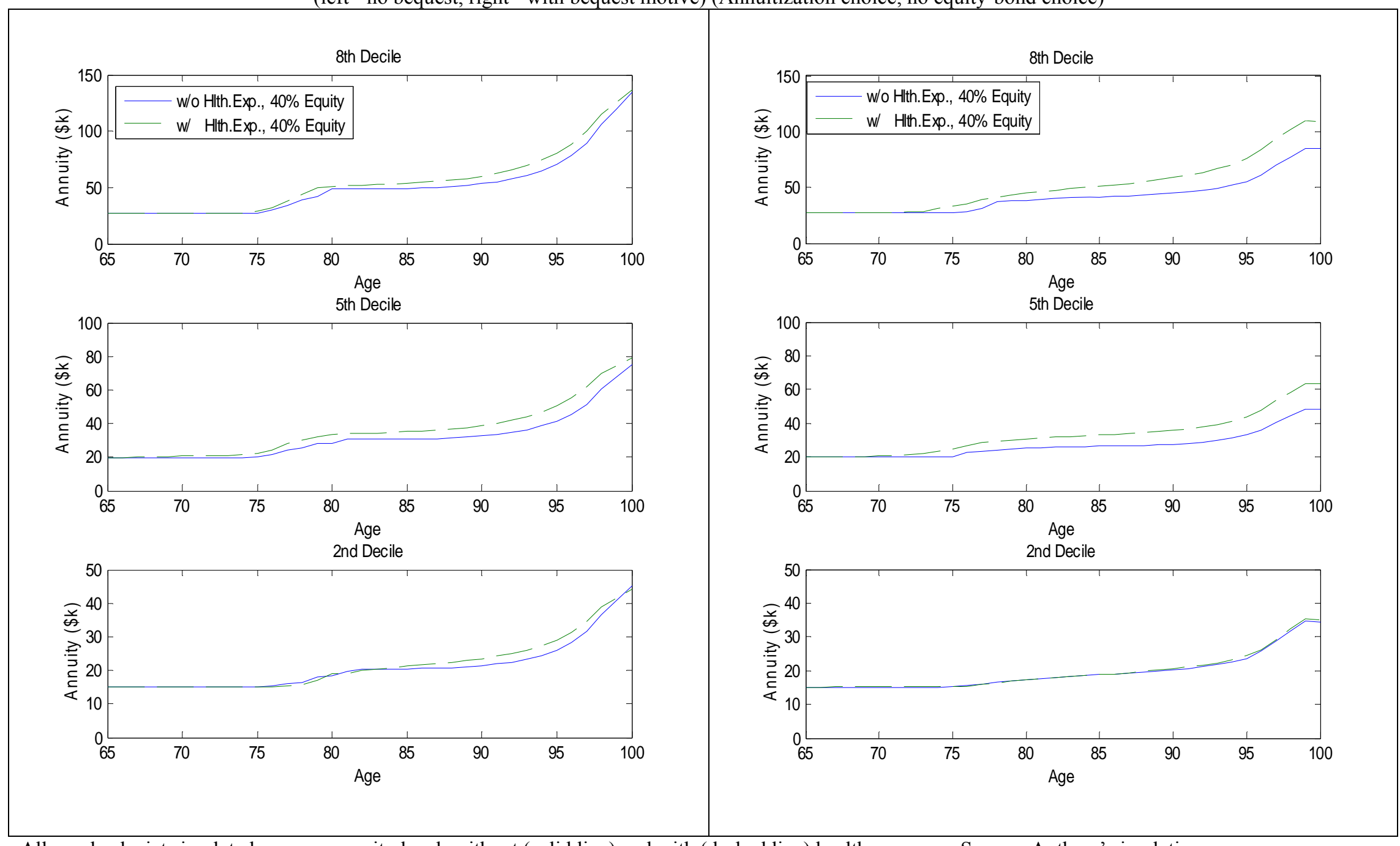

All graphs depict simulated average annuity level: without (solid line) and with (dashed line) health expenses. Source: Authors' simulations. 
Figure 8 Non-Annuitized Wealth by Income Deciles

(left - no bequest, right - with bequest motive) (Full vs. partial equity-bond-annuity choices)

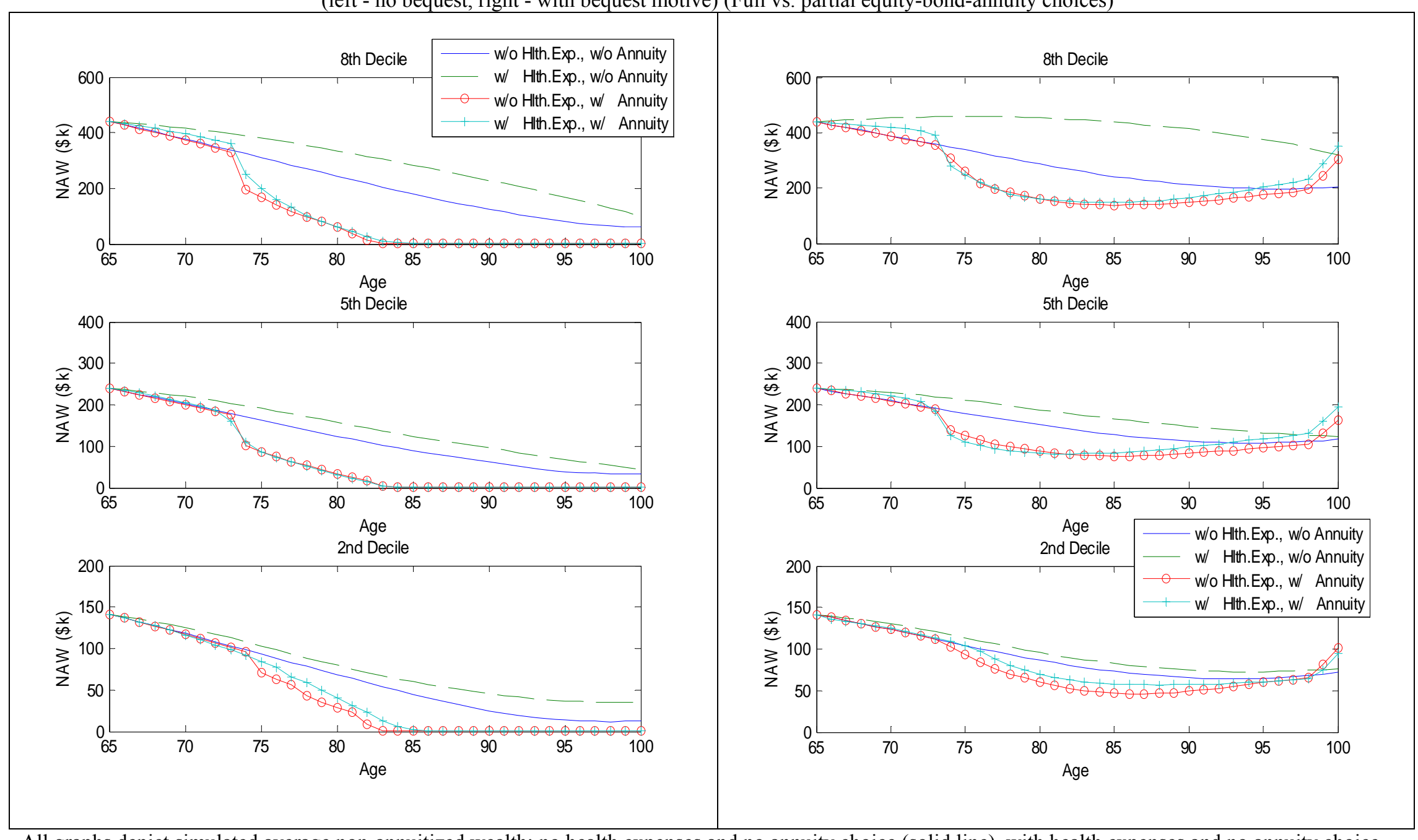

All graphs depict simulated average non-annuitized wealth: no health expenses and no annuity choice (solid line), with health expenses and no annuity choice (dashed line), no health expenses and with annuity choice (circled line), and with health expenses and annuity choice (plus line). Source: Authors' simulations. 
Figure 9 Annuity Level by Income Deciles

(left - no bequest, right - with bequest motive) (Full vs. partial equity-bond-annuity choices)

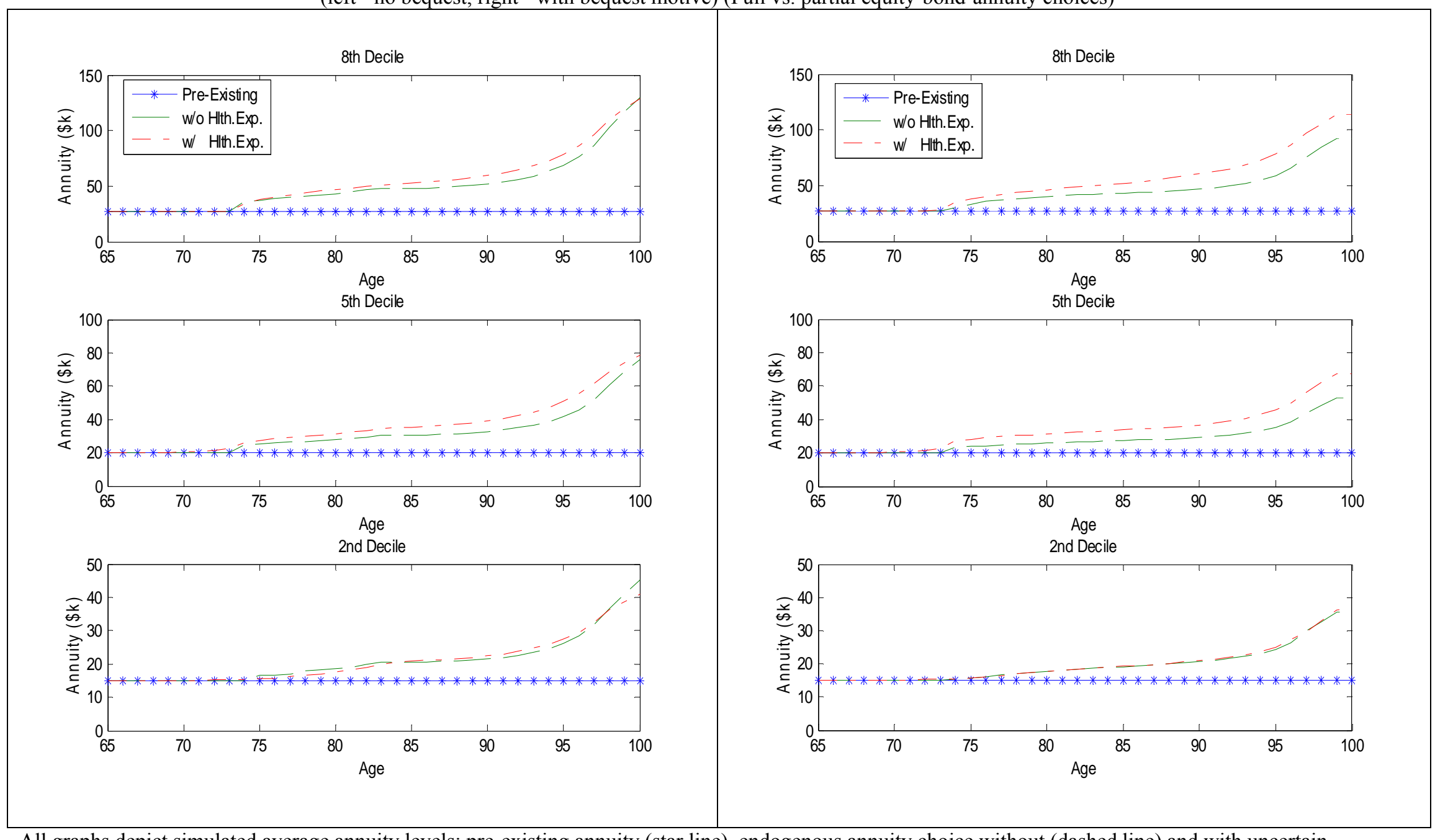

All graphs depict simulated average annuity levels: pre-existing annuity (star line), endogenous annuity choice without (dashed line) and with uncertain uninsured health expenses (dash-dotted line). Source: Authors' simulations. 
Figure 10a Equity Fraction of Non-Annuitized Wealth by Income Deciles

(left - no bequest, right - with bequest motive) (Full vs. partial equity-bond-annuity choices)

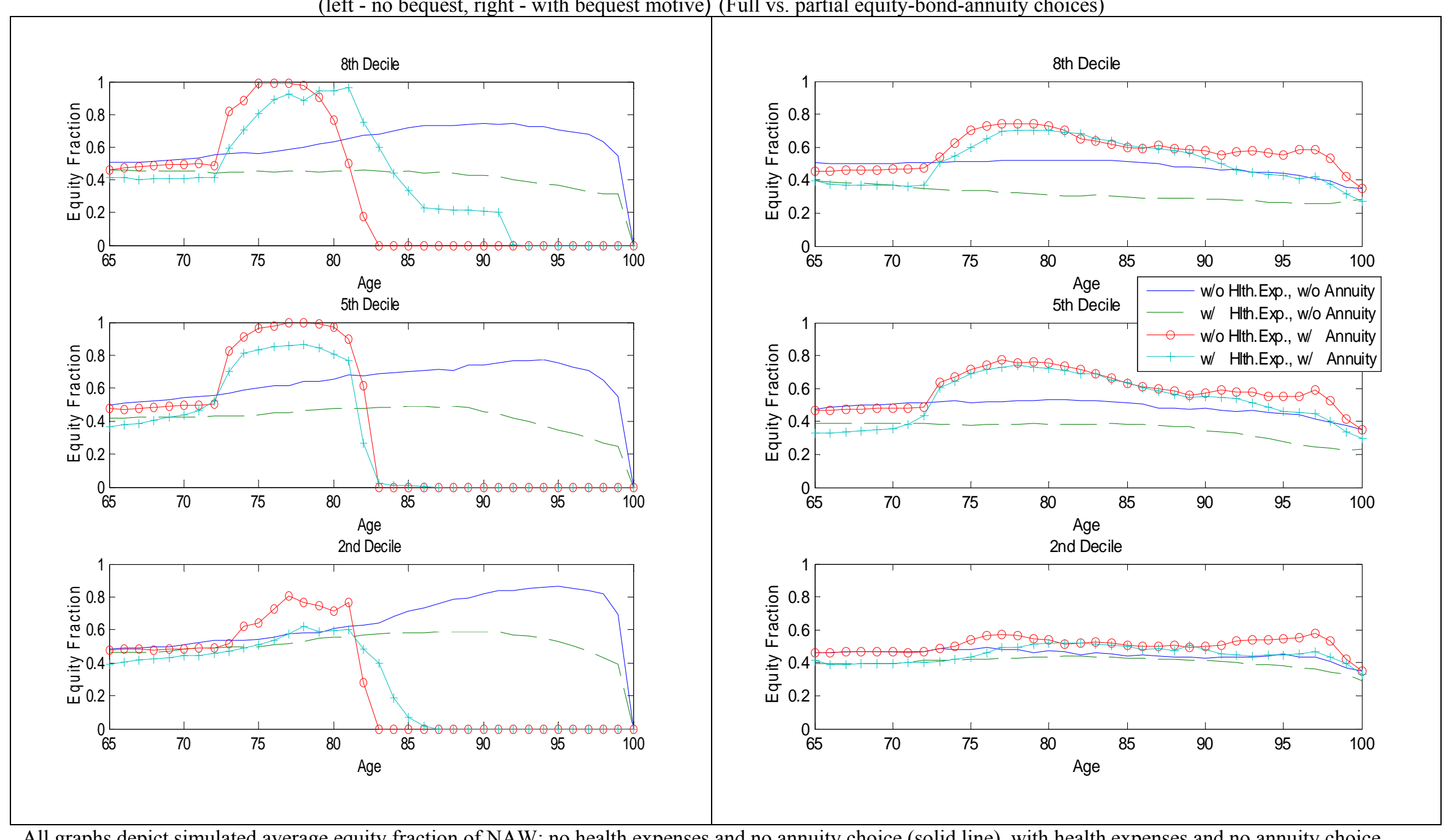

All graphs depict simulated average equity fraction of NAW: no health expenses and no annuity choice (solid line), with health expenses and no annuity choice (dashed line), no health expenses and with annuity choice (circled line), and with health expenses and annuity choice (plus line). Source: Authors' simulations. 
Figure 10b Optimal Annuity-Bond-Equity Allocations of Wealth by Income Deciles

(excluding pre-existing SS and DB wealth) (left - no health expenses, right - with health expenses)

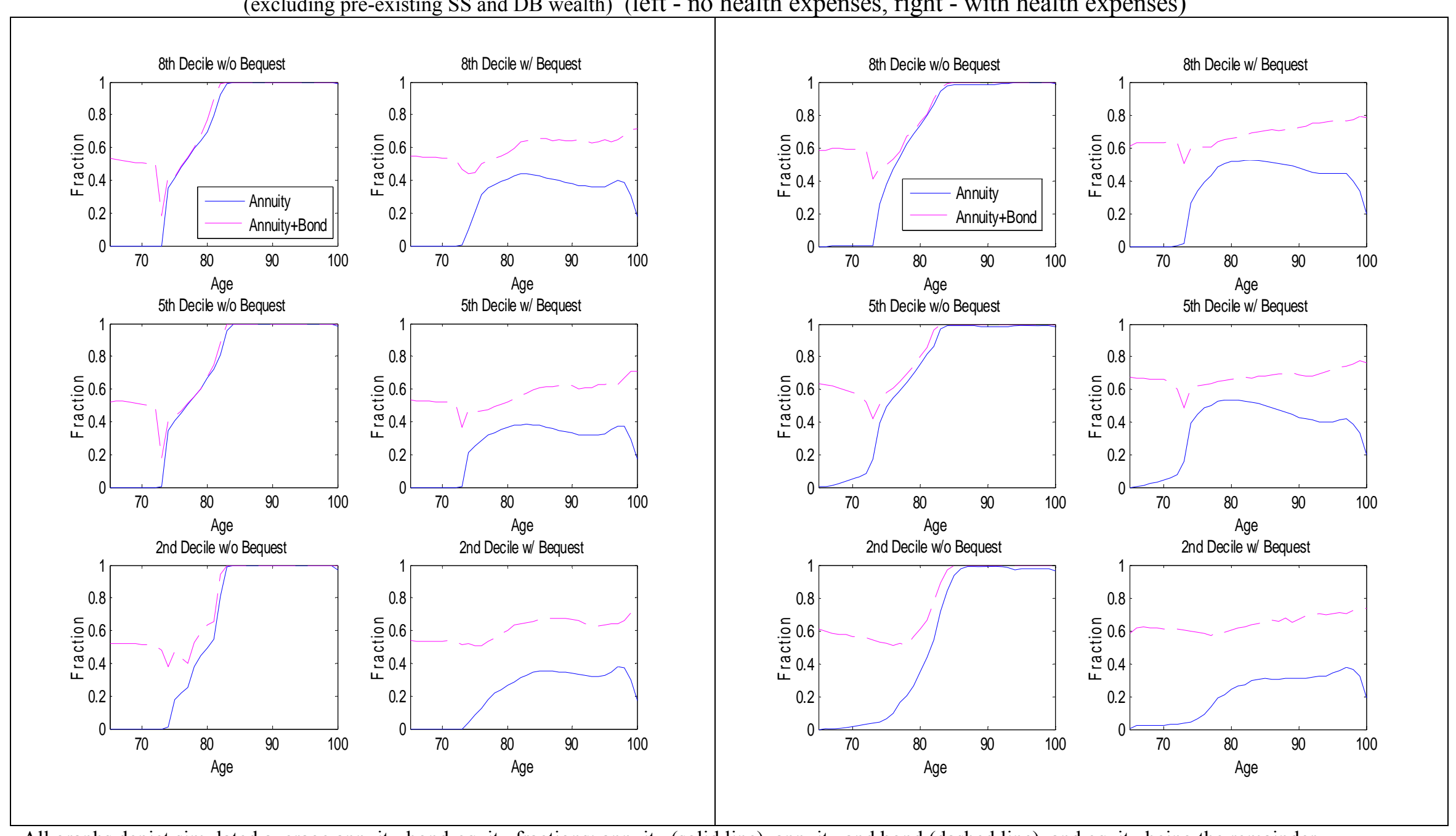

All graphs depict simulated average annuity-bond-equity fractions: annuity (solid line), annuity and bond (dashed line), and equity being the remainder. Source: Authors' simulations. 
Figure 11 Consumption by Income Deciles

(left - no bequest, right - with bequest motive) (Full vs. partial equity-bond-annuity choices)

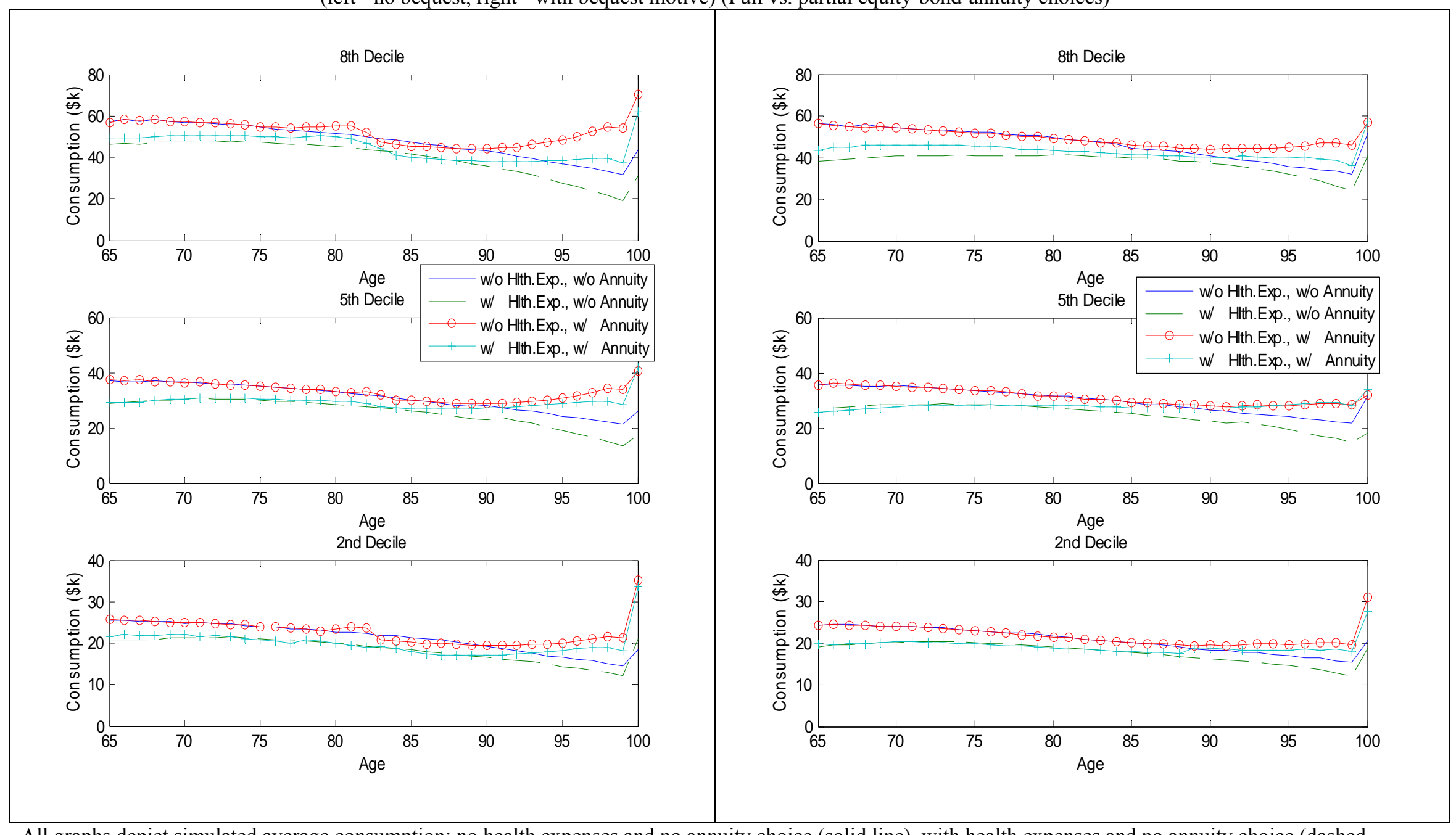

All graphs depict simulated average consumption: no health expenses and no annuity choice (solid line), with health expenses and no annuity choice (dashed line), no health expenses and with annuity choice (circled line), and with health expenses and annuity choice (plus line). Source: Authors' simulations. 
Table 1. Wealth Distribution for Households at 65 by Income Decile (Average, ‘04 \$000)

\begin{tabular}{lrrrrrrrrrr}
\hline Income Decile & \multicolumn{1}{c}{ 1 } & \multicolumn{1}{c}{2} & \multicolumn{1}{c}{3} & \multicolumn{1}{c}{4} & \multicolumn{1}{c}{5} & \multicolumn{1}{c}{6} & \multicolumn{1}{c}{7} & \multicolumn{1}{c}{8} & 9 & 10 \\
\hline 1. Non-Annuitized Wealth & 99.6 & 141.3 & 165.2 & 281.5 & 238.7 & 286.8 & 312.5 & 438.4 & 552.0 & 1054.8 \\
DC Plan + IRA & 35.7 & 47.0 & 55.3 & 95.3 & 71.5 & 92.9 & 99.3 & 127.0 & 175.4 & 296.6 \\
$\quad$ Half of Housing Equity & 39.0 & 48.1 & 53.8 & 64.1 & 69.9 & 76.2 & 79.6 & 114.1 & 112.6 & 191.5 \\
$\quad$ Financial Wealth & 24.9 & 46.2 & 56.1 & 122.1 & 97.3 & 117.6 & 133.5 & 197.3 & 264.1 & 566.7 \\
2. Pre-Annuitized Wealth & 229.6 & 248.9 & 284.8 & 313.4 & 330.2 & 370.6 & 413.4 & 451.5 & 499.1 & 644.6 \\
$\quad$ Social Security & 96.4 & 112.1 & 119.2 & 124.2 & 129.1 & 132.8 & 138.6 & 144.3 & 148.5 & 162.1 \\
$\quad$ Defined Benefit & 133.3 & 136.8 & 165.7 & 189.2 & 201.1 & 237.8 & 274.8 & 307.2 & 350.6 & 482.6 \\
3. Total Wealth (=1+2) & 329.3 & 390.2 & 450.0 & 595.0 & 568.9 & 657.3 & 725.9 & 889.9 & 1051.2 & 1699.4 \\
4. Annuity Share of Wealth & & & & & & & & & & \\
(=2/3) & $70 \%$ & $64 \%$ & $63 \%$ & $53 \%$ & $58 \%$ & $56 \%$ & $57 \%$ & $51 \%$ & $47 \%$ & $38 \%$ \\
\hline
\end{tabular}

Source: Authors' calculations based on Health and Retirement Study waves 1992-2004.

Table 2. Simulated Annual Health Expenses (ages 65-100, \$000)

\begin{tabular}{lrrrrrrrrrr}
\hline Income Decile & 1 & 2 & 3 & 4 & 5 & 6 & 7 & 8 & 9 & 10 \\
\hline 1.Mean of Expenses & 3.4 & 4.1 & 4.9 & 5.7 & 6.5 & 7.3 & 8.2 & 9.1 & 9.9 & 10.8 \\
2.Std. Dev. of Expenses & 3.4 & 4.1 & 4.9 & 5.9 & 7.1 & 8.6 & 10.4 & 12.5 & 15.0 & 18.1 \\
$\quad \begin{array}{l}\text { 3.Pre-Existing Annuity } \\
\quad \text { SS+DB annual payout) }\end{array}$ & 14.6 & 14.9 & 17.1 & 18.8 & 19.8 & 22.2 & 24.8 & 27.1 & 29.9 & 38.6 \\
$\quad \begin{array}{l}\text { 4.Health Expense Coverage } \\
\quad \text { Mean / Annuity }\end{array}$ & & & & & & & & & & \\
$\quad$ (Mean + 2*s.d.) / Annuity & $70 \%$ & $82 \%$ & $86 \%$ & $93 \%$ & $105 \%$ & $110 \%$ & $117 \%$ & $126 \%$ & $133 \%$ & $121 \%$ \\
\hline
\end{tabular}

Source: Authors' simulations. 


\section{Notes}

${ }^{1}$ It is straightforward to expand the retirement phase to an earlier age or a longer lifespan. However, the detailed estimates of health expenses are available only up to age 100 in de Nardi, French and Jones (2006)

${ }^{2}$ For consistency in our modeling, these annuity payouts, constant for ages 65-100 conditional on survival, are calculated using the household joint survival rates based on SSA life tables. This may to some extent understate the buffer effect of SS and DB payouts in early retirement years in that the household receipt of SS and DB payouts generally starts with a higher value but shrinks after one member passes away.

${ }^{3}$ Note also that the model assumes certain death at age 100 but the joint survival rate at age 99 remains relatively high directly based on the SSA life tables.

${ }^{4}$ The market average asset allocations are based on the fifteen lifecycle funds in the retirement phase available at www.morningstar.com on November 6, 2007.

${ }^{5}$ Recall furthermore that the buffer function of pre-existing Social Security and DB payouts in the early retirement years may be understated here. See footnote 2.

${ }^{6}$ As a double check, we also conduct an experiment assuming little initial assets for households and where the only income is Social Security benefit. Simulations show that they would first build up a certain cash balance and then eventually buy additional annuities in the presence of stochastic health expenses.

${ }^{7}$ Currently, the combined contribution to Social Security by employer and employee is 12.4 percent of the employee's earnings up to a cap. One of the proposals would divert 4 percent payroll tax (i.e., one third of the total contribution) into personal accounts. 